\title{
TEORES DE CAROÇO DE ALGODÃO EM DIETAS CONTENDO SILAGEM DE MILHO PARA VACAS EM LACTAÇÃO
}

\author{
JULIANO JOSÉ DE RESENDE FERNANDES \\ Medico Veterinário
}

Orientador: Prof. Dr. ALEXANDRE VAZ PIRES

Dissertação apresentada à Escola Superior de Agricultura "Luiz de Queiroz", Universidade de São Paulo, para obtenção do título de Mestre em Agronomia, área de Concentração Ciência Animal e Pastagens.

$P|R A C| C A B A$

Estado de São Paulo - Brasil

Abril - 2000 


\section{Dados Internacionais de Catalogação na Publicação (CIP) DIVISÃO DE BIBLIOTECA E DOCUMENTAÇÃO - Campus "Luiz de Queiroz"/USP}

Fernandes, Juliano José de Resende

Teores de caroço de algodão em dietas contendo silagem de milho para vacas em lactação / Juliano José de Resende Fernandes $67 \mathrm{p}$.

Dissertação (mestrado) - - Escola Superior de Agricultura Luiz de Queiroz, 2000. Bibliografia.

1. Ácido graxo 2. Caroço de algodão 3. Digestibilidade animal 4. Nutrição animal 5. $\mathrm{pH}$ 6. Proteina do leite 7. Silagem de milho 8. Teor de gordura 9. Vaca lactente I. Titulo

CDD 636.2085 
DEDICO

Aos meus amados país, JALME E ZILDA

Ao meu irmão e cunhada Marco Alexandre e Claudia

Ao meu irmão, Jalme Jr. (Gominha)

Aos Meus Avós, Geraldo , Mária (Vó Fia), Dimas e Lídia

Aos meus Sobrinhos Marco Alexandre e Ana Vitória 


\section{AGRADECIMENTOS}

À Deus por estar sempre ao meu lado.

À Escola Superior de Agricultura "Luiz de Queiroz" (ESALQ/USP) por intermédio do Departamento de Produção Animal, pela oportunidade e apoio de realização deste curso.

À Coordenação de Aperfeiçoamento de Pessoas de Nível Superior (CAPES), pela concessão de bolsa de estudo.

Ao Prof. Dr. Alexandre Vaz Pires, pela orientação, pelos valioso ensinamentos, pela amizade, pela confiança e pelos os exemplo de vida e profissional.

À Prof ${ }^{a}$. Dr ${ }^{\mathrm{a}}$. Ivanete Susin, pelos ensinamentos, pela amizade.

Ao Prof. Dr. José Manuel Correia de Simas, pelas sugestões na execução deste trabalho, pela atenção.

Ao Prof. Dr. Flávio Augusto Portela Santos, pelas sugestões, colaboração e ensinamentos.

Aos demais Professores do Departamento de Produção Animal, pelos ensinamentos e pela amizade.

Aos meus Pais Jalme e Zilda, irmãos Marco e Jalme Jr e cunhada Claudia, pelo amor, carinho, apoio e incentivo.

Aos meus tios João Toledo e Zulma que foram grandes amigos e ajudaram na minha formação.

A minha tia Dr. Maria França que foi um grande exemplo em minha vida.

Aos meus primos João Humberto e Ludmilla, que sempre estiveram juntos comigo quando precisei.

Aos colegas Reinaldo Cunha de Oliveira Jr., José Renato Silva Gonçaves, Laisse Garcia de Lima, Paulo Garcez de Oliveira, pela amizade e pela agradável convivência.

Aos estagiário Marcos de Bem (Simental), pela amizade e valiosa ajuda na execução do experimento de tese. 
Aos estagiários Karina (Dispaxo), Kelly (Pedra), Mariana (Help) e Fábio (Carijó), pela amizade, e valiosa colaboração em outros experimentos por mim conduzidos.

$A$ todos os estagiários do $\mathrm{CPZ}$, que estiveram sempre juntos e contribuíram com a realização desse trabalho.

Aos funcionários do DPA Laureano e Benedito, pelas suas colaborações sempre que precisei.

À Republica Zona Rural, que me acolheu quando precisei.

Aos funcionários e estagiários do Laboratório de Bromatologia do DPA, Carlos César e Karem, pelos ensinamentos e colaboração nas determinações laboratoriais.

Aos demais funcionários e colegas do curso de pós-graduação pela amizade e agradável convivência.

À todos que, diretamente ou indiretamente, contribuíram para realização deste projeto. 
6....

Deus! Dai-nos a força de ajudar o processo, a fim de subirmos até Vós; dai-nos a caridade pura; dai-nos a simplicidade que fará das nossas almas o espelho onde se deve refletir vossa imagem." 


\section{SUMÁRIO}

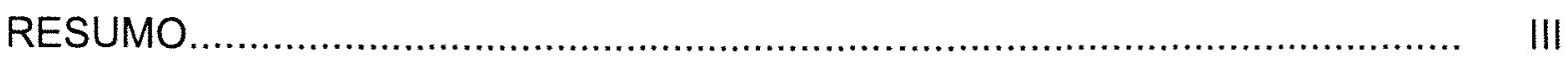

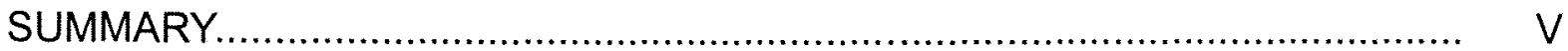

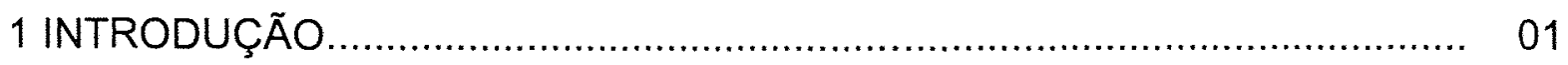

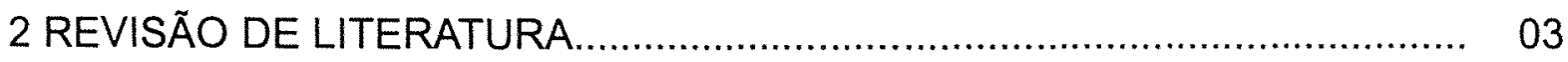

2.1 Fontes de gordura na alimentação animal............................................ 03

2.2 Digestão de lipídios nos ruminantes..................................................... 04

2.3 Digestibilidade dos nutrientes.......................................................... 07

2.4 Efeito da gordura no desempenho de vacas leiteiras............................ 08

2.5 Produção e composição do leite............................................................. 11

2.6 Gordura e fontes de forragem.......................................................... 13

3 MATERIAL E MÉTODOS..................................................................... 15

3.1 Animais e instalações experimentais.................................................. 15

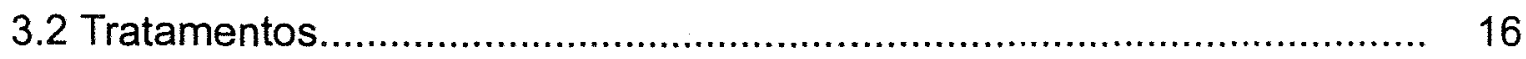

3.3 Período experimental...................................................................... 17

3.4 Adição de óxido de cromo (marcador externo)...................................... 18

3.5 Coletas de dados referentes ao alimentos oferecido e recusado para avaliação de consumo de matéria seca............................................... 18

3.6 Coleta de fluído ruminal para determinação de ácidos voláteis (AGVs) e pH ruminal................................................................................ 19

3.7 Coleta de fezes para determinação da digestibilidade aparente do trato

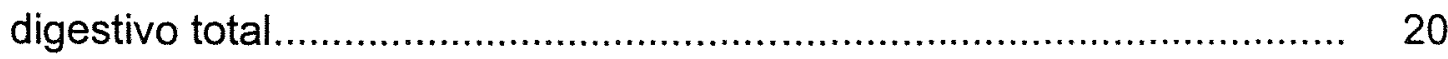

3.8 Coleta de conteúdo duodenal para determinação da digestibilidade de nutrientes e fluxo de proteína microbiana............................................... 20

3.9 Determinação da composição e da produção de leite.............................. 22

3.10 Digestibilidade in situ..................................................................... 22

3.11 Analise estatística......................................................................... 23

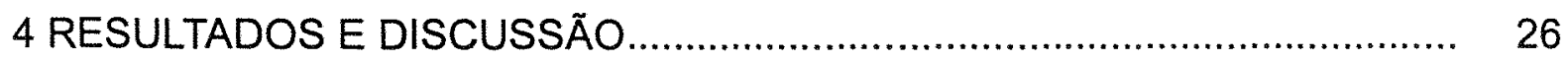

4.1 Consumo de matéria seca, produção e composição do leite .................. 26

4.2 Consumo e digestibilidade dos nutrientes no trato digestivo total........... 30

4.2.1 Matéria seca e matéria orgânica.................................................. 30 
4.2.2 Fibra em detergente neutro e fibra em detergente ácido .............. 33

4.2.3 Proteína bruta ........................................................................ 34

4.2.4 Extrato etéreo e energia bruta ............................................... $\quad 35$

4.3 Parâmetros ruminais..................................................................... 38

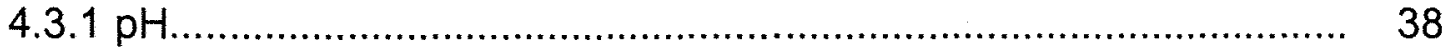

4.3.2 Concentração de ácidos graxos voláteis (AGVs) ……................. 39

4.3.2.1 Ácidos graxos voláteis totais.......................................... $\quad 39$

4.3.2.2 Ácido acético.................................................................. 41

4.3.2.3 Ácido propiônico........................................................... 44

4.3.2.4 Ácido butírico................................................................ 47

4.3.2.5 Relação acético/propiônico................................................ 49

4.4 Digestibilidade in situ .................................................................... 51

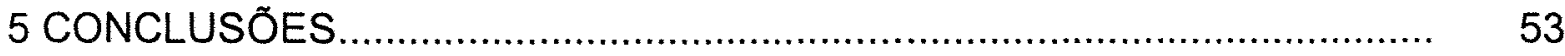

6 REFERENCIAS BIBLIOGRÁFICAS...................................................... 54 


\section{TEORES DE CAROÇO DE ALGODÃO EM DIETAS CONTENDO SILAGEM DE MILHO PARA VACAS EM LACTAÇÃO}

Autor: Juliano José de Resende Fernandes

Orientador: Prof. Dr. Alexandre Vaz Pires

\section{RESUMO}

Teores de caroço de algodão (CA) foram acrescentados à dieta de vacas holandesas para avaliar o consumo de matéria seca, digestibilidade de nutrientes, degradabilidade ruminal e parâmetros ruminais. Cinco vacas pluríparas com média de 200 dias de lactação foram fistuladas no rúmen e duodeno foram usadas em um quadrado latino $5 \times 5$. Os animais foram alimentados com dietas contendo $40 \%$ de concentrado e $60 \%$ volumoso. Os tratamentos foram níveis de $\mathrm{CA}(0,6$, 12,18 e $24 \%$ da MS de CA) em dietas contendo silagem de milho. A produção de leite ( $\mathrm{kg} / \mathrm{dia}$ ) e de proteína do leite ( $\mathrm{g} / \mathrm{dia}$ ) teve um comportamento quadrático, e apenas uma tendência quadrática na produção de leite corrigida para $3.5 \%$ de gordura, a porcentagem de gordura do leite aumentou $(P<0,05)$ linearmente. Houve uma tendência linear reduzindo o consumo de matéria seca e matéria orgânica, e uma diminuição linear $(P<0,05)$ da digestibilidade da MS e MO. A digestibilidade aparente de extrato etéreo aumentou $(P<0,05)$ linearmente com a adição de CA à dieta, já a digestibilidade aparente da PB, FDN, FDA, EB não sofreram alterações. Os parâmetros ruminais $(\mathrm{pH}, \mathrm{AGVT})$ não diferiram entres os tratamentos. Os ácidos graxos $\left(\mathrm{C}_{2}\right.$ e $\left.\mathrm{C}_{3}\right)$ e a proporção $\mathrm{C}_{2}: \mathrm{C}_{3}$ tiveram um efeito quadrático, o ácido butírico teve uma diminuição linear. $A$ degradabilidade efetiva da matéria seca nas taxas de passagem de 2,5 e $8 \% / h$, a fração rapidamente solúvel e insolúvel em água não sofreram alterações, já a degradabilidade do 
material insolúvel diminuiu linearmente e a degradabilidade potencial aumentou linearmente. 


\section{COTTONSEED LEVELS IN CORN SILAGE BASED DIETS FOR LACTATING HOLSTEIN COWS}

Author: Juliano José de Resende Fernandes

Adviser: Prof. Dr. Alexandre Vaz Pires

\section{SUMMARY}

Five cannulated ( rumen and proximal duodenum) mature Holstein cows, averaging 200 days in milk, were used in a $5 \times 5$ latin square design to evaluate the dry matter intake, nutrient digestibility and ruminal parameters of diets containing cottonseed. The experimental treatments were: T0, T6, T12, T18 and T24 corresponding to $0,6,12,18$ or $24 \%$ of cottonseed in the diet. The cows were fed $40 \%$ concentrate and $60 \%$ corn silage. Milk production ( $\mathrm{kg} /$ day) and milk protein (g/day) had a quadratic response while fat corrected milk production had a quadratic tendency. There was a tendency to reduce dry matter and organic matter intake. Dry matter apparent digestibility were reduced $(P<0.05)$ linearly. Ether extract apparent digestibility was increased $(P<0.05)$ linearly. Apparent digestibility of crude protein, neutral detergent fiber and crude energy were not altered. Acid detergent fiber apparent digestibility was reduced $(P<0.05)$ linearly. Ruminal $\mathrm{pH}$ and total volatile fatty acids did not differ among treatments. Acetate and propionate concentration and acetate:propionate ratio had a quadratic response while butyrate was reduced $(P<0.05)$ linearly. The effective degradability of dry matter on rate of passage of 2,5 and $8 \% / h$, as well as the rapidly soluble and insoluble in water fractions were not changed, although the degradability of insoluble fraction decreased $(P<0.05)$ linearly and the potential degradability increased $(P<0.05)$ linearly. 


\section{INTRODUÇÃO}

Os benefícios de se aumentar o teor de lipídios nas dietas para vacas em lactação foram amplamente documentados em inúmeros trabalhos de pesquisa e extensas revisões. A utilização de alimentos ricos em lipídios na dieta de ruminantes é de grande valia por aumentar a densidade energética da dieta, sem aumentar os riscos de ocorrências de acidose ruminal. Entretanto, a adição desses nutrientes à dieta em quantidades consideráveis pode prejudicar a digestibilidade de fibra no rúmen, e assim comprometer o desempenho animal.

A utilização de vacas leiteiras com potencial genético cada vez maior, tem resultado em exigências nutricionais elevadas, aumentando a importância de estudos com fontes alimentares capazes de suprir está demanda nuticional.

Uma vaca de alta produção requer altas quantidades de proteína e energia, mas também a fibra é importante para manter um padrão de fermentação ruminal adequado. $O$ requerimento de energia não é importante somente durante o primeiro trimestre, mas também é necessário para manter a persistência de produção e o ganho de peso no final da lactação. À medida que o potencial genético aumenta, a crescente demanda energética tem sido tradicionalmente atendida pelo aumento na participação de alimentos concentrados na dieta. As ingestões de concentrados comumente se aproximam de $50 \%$ da matéria seca consumida; valores entre 60 e $80 \%$ podem eventualmente ocorrer. O fornecimento de altas quantidades de carboidratos altamente fermentáveis a vacas de alta produção pode ocasionar vários 
problemas. Tais como: diminuição do teor de gordura do leite, redução da digestibilidade da fração fibrosa da dieta, decréscimo na eficiência bruta de conversão da energia dos alimentos, acidose ruminal, timpanismo, laminites, problemas hepáticos e queda na persistência de produção de leite.

Ferguson et al (1988) mostraram que a persistência de lactação pode ser aumentada com a suplementação de lipideos, mesmo durante a fase de declínio da produção de leite. Observações de campo têm demostrado um aumento no consumo de energia líquida em animais submetidos a condições de elevadas temperaturas ambientais, incremento na taxa de ganho de peso em animais primíparos, menor perda de peso em animais em início de lactação e aumento na eficiência reprodutiva quando lipídios são adicionados a dietas para gado leiteiro.

Uma das fontes de gordura mais utilizadas em fazendas especializadas em produção leiteira é o caroço de algodão , o qual contem 2,22 Mcal $/ \mathrm{kg}$ de ELL, $23 \%$ de proteina bruta, $44 \%$ de FDN, e $34 \%$ de FDA (NRC, 1989). A fibra é constituída uma parte pelo linter ( $10 \%$ do peso do caroço de algodão), que é de alta digestibilidade. $O$ caroço de algodão é relativamente rico em proteína comparado com grãos de cereais, e pode suprir uma importante porção do requerimento de proteína de uma vaca leiteira $A$ energia reflete o óleo que ele contem ( $20 \%$ da MS). O caroço de algodão tem sido utilizado no teor máximo de $15 \%$ do total da dieta de vacas leiteiras, para minimizar o efeito da gordura insaturada na fermentação ruminal.

O objetivo desse estudo foi testar teores crescentes de caroço de algodão $(0 \% ; 6 \% ; 12 \% ; 18 \%$ e $24 \%)$ na MS da dieta de vacas holandesas pluríparas em meados para o final de lactação, (com produção superior a $15 \mathrm{~kg}$ de leite/dia), alimentadas com silagem de milho como fonte de volumoso. Os parâmetros avaliados foram: digestibilidade dos nutrientes no trato digestivo total; degradabilidade ruminal das dietas; concentração de ácidos graxos voláteis no rúmen; pH ruminal; consumo de MS e produção e composição do leite. 


\section{REVISÃO DE LITERATURA}

\subsection{Fontes de gordura na alimentação animal}

As gorduras estão presentes na proporção de 3-10\% da matéria seca das forragens, as quais utilizam as gorduras como uma forma secundária de estocar energia. Geralmente, a gordura é estocada na forma de triglicerídeos nos grãos de plantas oleaginosas e contem altos níveis de ácidos graxos insaturados (Byers et al., 1988).

As fontes vegetais de gordura mais utilizadas para ruminantes, são as sementes de oleaginosas, entre elas o caroço de algodão e o grão de soja, devido a sua disponibilidade em várias regiões do Brasil e seu preço acessivel. O caroço de algodão possui $2,22 \mathrm{Mcal} / \mathrm{kg}$ de ELL, $23 \%$ de proteína bruta, $44 \%$ de FDN, e $34 \%$ de FDA (NRC, 1989). A fibra é constituída em parte pelo "linter" ( $10 \%$ do peso do caroço de algodão), que é composta de celulose de alta digestibilidade. A energia reflete o óleo que ele contém ( $20 \%$ da MS). O caroço de algodão geralmente é utilizado até $15 \%$ do total da dieta para minimizar o efeito da gordura insaturada na fermentação ruminal.

As fontes de gordura de origem animal são ricas em ácidos graxos saturados, menos prejudiciais a fermentação ruminal. Entretanto apresentam maiores dificuldades para sua utilização devido, além da falta de controle de produtos de origem animal. 


\subsection{Digestão de lipídios nos ruminantes}

Os lipídios são substâncias insolúveis em água, porém solúveis em éter, clorofôrmio e benzeno, e são encontrados nas plantas de várias formas, as quais por sua vez, são importantes na sua utilização e na sua interação com os outros componentes da ração (Byers et al., 1988).

Os triglicerídios ao chegarem ao rúmen são rapidamente hidrolizados e transformados em três ácidos graxos e um glicerol. A proporção de hidrólise dos triglicerídios está intimamente ligada à fonte destes. Desta forma podemos ter uma hidrólise de até $90 \%$ em plantas oleaginosas, ou apenas $50 \%$ em fontes como a gordura do óleo de peixe (Byers et al., 1988). O tipo de ácido graxo formado também é dependente da fonte utilizada na dieta, podendo ser ácidos graxos insaturados ou saturados. Os insaturados sofrerão um biohidrogenação ruminal. Esse processo é a adição de átomos de hidrogênio as duplas ligações dos ácidos graxos. Esse processo é bastante importante pois os microorganismos utilizam os hidrogênios livres no rúmen. Se houver tempo de permanência do ácido graxo no rủmen todas as duplas ligações são desfeitas e transformadas em simples( Byers et al., 1988).

Os lipídios, na sua maioria, chegam ao duodeno dos ruminantes na forma de finas camadas de ácidos graxos livres, na superfície da partículas de alimentos. Reiser et al. (1956) demostrou que os ácido graxos insaturados são hidrogenados no rúmen por microrganismos ali presentes. Essa biohidrogenação dos ácido graxos de cadeia longa aparentemente ocorre somente depois da hidrólise.

A digestão de gordura se inicia no rúmen. Bactérias lipolíticas, quebram a gordura em ácidos graxos e glicerol. O glicerol é utilizado como fonte de energia para microorganismos e é convertido para ácido propionico. Depois da lipolise ocorre a saturação (biohidrogenação; $\mathrm{BH}$ ) por bactéria biohidrogenadoras. Os ácido graxos seguem para o intestino delgado onde podem ser ab- 
sorvido. Ácidos graxos insaturados devem ter um grupo carboxila livre para ser biohidrogenado (Harfoot, 1981, Kepler et al., 1970), mas alguns ácidos graxos poliinsaturados podem passar pelo rúmen sem sofrerem biohidrogenação. $A$ probabilidade da ocorrência deste fato é devido a falta de lipolise (Palmquist e Jenkins, 1980) ou a rápida velocidade de passagem da matéria seca. Passagem de $\mathrm{C}_{18: 2}$ pode também ser entendida devido a aderência deste as partículas solidas criando uma proteção ante bactérias impedindo a biohidrogenação.

A composição da dieta tem um efeito pequeno na biohidrogenação. Gerson et al (1983) descobriram que o acréscimo de $N$ da dieta de 0,7 para 2,5 $\%$, aumentou a velocidade de lipolises e biohidrogenação . Dietas com $1 \%$ de $N$ promovem um aumento nos ácidos graxos insaturados no rúmen. Os autores sugeriram que esse fenômeno pode ser devido a uma troca de população microbiana na dieta com baixa concentração de nitrogênio. O número de organismos lipoliticos e biohidrogenadores diminuem com o aumento de grãos na dieta (Palmquist e Jenkins, 1980). Bactérias e protozoários ruminais podem incorporar ácidos graxos como lipidios celulares, e ambos também podem sintetizar ácidos graxos de cadeia longa (Harfoot, 1991). Alguns tipos de óleo especialmente aqueles que possuem ácidos graxos com 20 a 22 carbonos polinsaturados (ex.: óleo de peixe), inibe o crescimento microbiano no rúmen, (Palmquist e Jenkins, 1980).

A origem da gordura também tem efeito na composição e população microbiana do rúmen. Inclusão de gordura na dieta, aumenta o total de ácidos graxos contidos nas bactérias ruminais. Erwin et al, (1963) demonstraram que a composição de ácidos graxos das bactérias ruminais refletem a composição de ácidos graxos contidos na dieta. Da mesma forma Bauchart et al. (1990) também demostraram que a concentração de ácidos graxos contidos nas bactérias ruminais aumento de 39 para $138 \%$ quando vacas foram suplementadas com gordura. Klusmeyer e Clark (1991) observaram que sabão de Ca na dieta, aumentou a concentração total de ácidos graxos $(154,4 \times 115,0 \mathrm{~g} / \mathrm{kg}$ de $\mathrm{MO})$ 
nas bactérias comparado com a dieta controle (não suplementado com gordura ).

Tice et al. (1994) demonstraram que vacas alimentadas com sabão de $\mathrm{Ca}$ tem mais $\mathrm{C}_{16}$ e menos $\mathrm{C}_{18}$ que vacas alimentadas com soja. Protozoários também alteraram sua composição de acordo com a fonte de gordura. Mohamed et al. (1988) utilizando $40 \%$ de silagem de milho , $15 \%$ de feno de alfafa e $45 \%$ de concentrado (baseado na Matéria Seca) na dieta de vacas em lactação, observaram que o número de protozoários não foi afetado com o aquecimento de sementes (caroço de algodão e soja) mas houve decréscimo na ingestão de matéria seca quando utilizou óleos livres e semente integral crua. Os ácidos graxos insaturados são mais tóxicos que os saturados para os microorganismos ruminais e são particularmente inibidores do crescimento microbiano (Henderson, 1973).

A esterificação de ácidos graxos também é um fator que influencia a digestibilidade ruminal. Palmquist e Conrad (1980) demonstraram que alimentação com 3,3\% da mistura sendo proveniente de gordura vegetal e animal (50\% de ácidos graxos esterificado) ou sebo tem similar utilização para vacas em lactação. Alimentando com sebo hidrogenado ou triglicerideos nos niveis de $2 \mathrm{e}$ $5 \%$ da MS, Eastridge e Firkins (1991) observaram que os triglicerídios foram mais inertes ao rúmen. Por outro lado, substituindo milho moído por sebo 0,2 , 4, e $6 \%$ da MS, Drackley e Elliot (1993) observaram que o acréscimo de sebo aumentou ligeiramente o $\mathrm{N}$ digestivel no trato total e a adição de sebo não afetou a ingestão de MS e as caracteristicas da fermentação ruminal. 


\subsection{Digestibilidade dos Nutrientes}

Várias teorias foram propostas por Devendra e Lewis (1974) para explicar a redução na digestão de fibra nos ruminantes alimentados com dietas ricas em gordura por meio da inibição da atividade microbiana, sedo essas: 1) Efeito ativo - superficial na membrana celular, 2) camada de ácidos graxos na superfície da fibra, 3) modificação da população microbiana devido ao efeito toxico dos ácidos graxos, e 4) redução da disponibilidade de cátions afetando o $\mathrm{pH}$. Todos esse efeitos levam para uma diminuição na produção ruminal de proteína microbiana assim como a redução da digestibilidade de nutrientes.

Gordura animal integral deve ser derretida antes de misturar com outros nutrientes da dieta. Embora mais dados sejam necessários, a recomendação tem sido para misturar a gordura primeiramente com a porção concentrado da ração total, depois misturar com a forragem. Para determinar se o método de incorporação de $5 \%$ de sebo na ração total para vacas em lactação tem algum efeito na digestibilidade da MS, Drackley et al (1994) acrescentaram gordura ao concentrado, ao feno ou como o ultimo ingrediente da ração total. Eles descobriram pequeno efeito na ingestão de MS, produção e composição do leite, características ruminais, e digestibilidade total. Servindo livremente óleo vegetal por cima do alimento ou na forma de ração total também aumenta a chance de reduzir a digestão da fibra e porcentagem de gordura do leite, (Mohamed et al., 1988). Entretanto, esse efeito é minimizado se o óleo está dentro de uma semente e introduzido no rúmen em pequenas porções em varia vezes e em forma de ração total, (Mohamed et al., 1988). Segundo essa recomendação, soja e caroço de algodão íntegros podem ser alimento de altas proporções relativas na dieta total (Knapp et al., 1991; Smith et al., 1981). Leonardo e Block (1988) não observaram diferença no desempenho animal quando $33 \%$ da MS da dieta em ração total , era de soja tostada ou soja crua. Os inibi- 
dores de tripsina achados em soja crua reduzem a digestão no intestino delgado mas a extensão desta redução foi relativamente pequena ( Tice et al., 1993).

Dietas gordurosa são mais prejudiciais para os protozoários do rúmen que para bactérias (Czerkawaki, 1973; Horner et al., 1988; Kajikawa et al., 1991; Mohamed et al., 1988). Kajikawa et al (1991) observaram um decréscimo na relação ruminal de acético e propiônico quando $4 \mathrm{~kg} / \mathrm{dia}$ de caroço de algodão integral foram oferecido para vacas em lactação. Os autores sugeriram que o decréscimo no número de protozoários e no metabolismo bacteriano foram responsáveis por esse resultado.

O caroço de algodão é um alimento interessante por possuir alto teor de fibra e energia ao mesmo tempo (é composto por aproximadamente $35 \%$ de forragem" (linter) e $65 \%$ de "concentrado" (óleo mais farelo)). Smith et al. (1981) utilizando feno de alfafa como fonte de volumoso forneceu $0,5,15 \mathrm{e}$ $25 \%$ da MS de caroço de algodão para vacas e observou consumo de 19,7; 19,$0 ; 19,1$ e $20,4 \mathrm{~kg} / \mathrm{dia}$ e um consumo de energia liquida de 30,$8 ; 29,8 ; 31,3$ e $34,8 \mathrm{Mcal} / \mathrm{dia}$, respectivamente.

A inclusão de caroço de algodão nas proporções de 15 a $20 \%$ da MS da dieta não afetou a fermentação ruminal e a digestibilidade dos nutrientes (Palmquist \& Conrad,1978).

\subsection{Efeito da gordura no desempenho de vacas leiteiras}

Vacas de alta produção tem grande requerimento de energia, especialmente no primeiro trimestre da lactação. O pico de lactação ocorre antes do pico de ingestão de matéria seca (IMS), gerando um déficit energético para a vaca. Teoricamente, a suplementação com gordura nesta fase poderia promover uma adição de energia sem diminuir niveis de forragem na dieta. Entretanto inúmeros trabalhos têm demonstrado que não há beneficio na adição de gordu- 
ra em niveis normais à dieta durante as primeiras 5 à 7 semanas de lactação (Hoffman et al., 1991; Jerred et al., 1990; Ruegsegger \& Schultz, 1985). Quando vacas atingem balanço energético positivo, elas parecem responder melhor à adição de gordura na dieta. Entretanto, a perda de peso não pode ser reduzida com a adição de gordura na dieta (Skaar et al., 1989), mas o ganho pode ser acelerado primeiro em vacas com balanço energético positivo. A razão pelo qual não se encontrou respostas durante o início da lactação, parece ser devido à redução no consumo, neutralizando o ganho no aumento da densidade energética.

Palmquist (1987) demonstrou vantagens no uso de gordura para vacas leiteiras: 1) a densidade energética da gordura é maior que a dos ingredientes que ela substitui; 2$)$ os ácidos graxos de cadeia longa $\left(C_{16} \quad C_{22}\right)$, são utilizados com alta eficiência nas vacas em lactação porque eles podem ser diretamente transferidos para a gordura do leite; 3 ) a mantença na ingestão de fibra aumentando a densidade energética, melhora a desempenho reprodutivo, persistência da produção de leite e saúde do animal (ex.: menos cetose), e 4) redução no custo da alimentação. Fonte de gordura para a alimentação incluem sementes oleaginosas (soja, caroço de algodão, semente de girassol e canola), e gordura animal (sebo, toucinho, banha) que podem ser misturadas com óleo vegetal, hidrogenados, ou associado com cátions (ex.: $\mathrm{Ca}^{++}$) para formar grânulos de gordura.

Apesar da substituição de fontes de carboidratos por gordura em dietas para vacas em lactação aumentar a sua densidade energética, uma resposta positiva pode não ocorrer, quando há diminuição no consumo voluntário do animal (Jenkins \& Jenny 1989). A gordura pode também influenciar a digestão de outros nutrientes ou a sua própria digestão e absorção (Coppock et al., 1991).

Comparando o efeito de gordura granulada, ácidos graxos, gordura granulada de sebo hidrogenado e ácidos graxos floculados na digestibilidade de ácidos graxos e outros nutrientes, Elliot et al (1994) concluíram que a digestibi- 
lidade dos ácidos graxos $\mathrm{C}_{16}$ e $\mathrm{C}_{18}$ foram diminuídas quando vacas foram alimentadas com sebo hidrogenado e que a estrutura química e a fonte de gordura (trigliceridios $X$ ácidos graxos) foram mais responsáveis pela variação na digestibilidade dos ácidos graxos. Também a esterificação e o grau de saturação são importantes quando se processa a gordura para uso na alimentação de ruminantes. Ácidos graxos comparado com trigliceridios têm demostrado a redução na relação aceto : propionato no rúmen (Chalupa et al., 1986). Ácidos graxos de cadeia curta e média podem ser absorvidos pelas células do epitélio ruminal e ir para circulação sangüínea ou eles podem ser utilizado pelas células do epitélio ruminal (Hild et al., 1966). Ácidos graxos de cadeia longa (AGCL) são menos solúveis na digesta. Essa é uma das razões porque os AGCL não são absorvidos pela parede ruminal.

Usando diferentes combinações de gordura granulada e óleo de canola, Jenkins e Jenny (1992) observaram que utilizando apenas gordura granulada aumentou a produção de leite, composição da gordura do leite; entretanto a, proteína do leite foi reduzida. A digestibilidade da MS e da fibra no trato total foram a mesma para o controle e dietas com suplementos gordurosos apesar de ocorrer efeito negativo do óleo de canola nos ácidos graxos voláteis e relação acetico : propionico no rúmen. Alimentos gordurosos para ruminantes comumente causam uma mudança na digestão da fibra no rúmen para 0 intestino grosso. (Boggs et al., 1987; Jenkins \& Fotoouhi., 1990).

Em sua revisão Coppock et al. (1987) demostrou não haver diferença $(p>0,05)$ na ingestão de matéria seca quando caroço de algodão foi incluído na dieta até níveis de $25 \%$ da matéria seca.

Villela et al. (1997b) utilizando niveis de caroço de algodão no concentrado de $0,10,20$ e $30 \%$ para vacas $7 / 8$ holandesas, observou um efeito quadrático na digestibilidade de ruminal de FDN. Já a digestibilidade da matéria seca, matéria orgânica, proteína bruta e extrato etéreo não foram influenciados pela adição de caroço de algodão ao concentrado. Com essa mesma dieta os autores não encontraram diferença na eficiência de síntese microbiana pela 
adição de caroço de algodão, e também não foi encontrado diferença no $\mathrm{pH}$ e concentração de amônia ruminais (Villela et al. 1997a).

O processamento do caroço de algodão foi avaliado por Teixeira et al. (1996), utilizando caroço de algodão e milho nas formas integro e moido na proporção de $26,1 \%$ e $61,5 \%$ respectivamente da porção concentrada da ração. Os autores concluíram que o processamento físico desses ingredientes aumentou a degradabilidade ruminal da matéria seca, proteína bruta e fibra em detergente neutro.

\subsection{Produção e Composição do Leite}

O efeito na composição do leite devido a adição de gordura a dieta varia e depende do tipo de gordura utilizada (Palmquist e Jenkins, 1980). Lipídios que são protegidos da fermentação ruminal e biohidrogenação causam um aumento na porcentagem de gordura do leite, produção total de gordura, e proporção de AGCL na gordura do leite, e decrescem proporção de ácidos graxos de cadeia curta na gordura do leite (Astrup et al., 1976; Goering et al., 1977; Kronfeld et al., 1980; MacLeod et al., 1977; Mattos e Palmquist, 1974; Smith et al., 1978

A suplementação com fonte de gordura, incluindo as com caroço de algodão, tem resultado no aumento na produção de leite (Anderson et al., 1979; MacLeod et al., 1977; Smith et al., 1981) e aumento na porcentagem de gordura do leite ( DePerts et al., 1985; Ma Leod et al., 1977; Palmquist e Moser, 1981; Smith et al., 1981). A digestão da celulose do linter produz principalmente ácido acético que é usado para síntese de gordura do leite. Kajikawa et al. (1991) ofereceram de 2 a $4 \mathrm{~kg} /$ dia de caroço de algodão, para vacas recebendo silagem de milho como volumoso e concluíram que $2 \mathrm{~kg} / \mathrm{dia}$ de caroço do algodão pareceu ser mais eficaz, para aumentar o teor de gordura do leite. Entretanto, a 
suplementação com gordura geralmente diminui a porcentagem de proteína do leite (Anderson et al., 1979; DePeters et al., 1985; Dunkley et al., 1977; Palmquist e Moser 1981; Smith et al., 1981). Palmquist e Jenkins (1980) observaram que o decréscimo da porcentagem de proteína do leite quando caroço de algodão foi acrescentado na dieta não é especifico porque isso ocorre com outras formas de suplementação gordurosa. O mecanismo no qual a gordura causa redução na porcentagem de proteína do leite ainda não foi bem definida. Palmquist e Moser (1981) sugeriram que a suplementação com gordura pode induzir uma redução em insulina e causar redução no trafego de aminoácidos para dentro da glândula mamaria, reduzindo a síntese de proteína do leite.

Alimentando vacas leiteiras com 0,10,15 e 20\% de caroço de algodão e $50 \%$ da MS de feno de alfafa, DePerters et al. (1985) descobriram que a produção de leite e a porcentagem de gordura do leite e sólidos totais aumentaram, e a porcentagem de proteína do leite diminuiu quando níveis de caroço de algodão aumentaram. Resultados semelhantes foram encontrados em outros trabalhos (Anderson et al., 1979; Smith et al,. 1981).

Segundo Palmquist (1989), de uma maneira geral, pode-se considerar que uma ração "normal" para vacas em lactação (alfafa, silagem de milho, milho e farelo de soja) contém cerca de $3 \%$ de ácidos graxos. As fontes comerciais convencionais de lipídeos (sebo, mistura de lipidios de origem animal e vegetal) ou ainda sementes integrais de oleaginosas (algodão, soja, etc.) podem ser utilizadas de modo a proporcionar uma suplementação de 2 a \% de ácidos graxos (cerca de $0,5 \mathrm{~kg}$ de lipídeo) em rações para vacas em lactação , a um custo moderado (nos Estados Unidos). Assim, se o desejável é atingir níveis de 5 a $6 \%$ de lipídios totais na dieta deve-se adicionar cerca de 2 a $3 \%$ de lipídios inertes em sua matéria seca. Em resumo, com uma dieta combinando alimentos convencionais e lipidios inertes, uma vaca de alta produção (consumindo $4 \%$ de seu peso em matéria seca/dia) pode utilizar aproximadamente $3 \mathrm{~g}$ de ácidos graxos $/ \mathrm{kg}$ de peso (o total de 1,8 kg para um animal de $600 \mathrm{~kg}$ ). 
Outra alternativa, que serviria de orientação, é o fornecimento de lipidios na mesma quantidade em que são secretados no leite diariamente.

\subsection{Gordura e Fontes de Forragem}

A interação do caroço de algodão com a fonte de volumoso é evidenciada na composição de sólidos totais do leite no experimento de Smith (1993) e Chik et al. (1987). Esses autores observaram um efeito negativo na composição de sólidos totais do leite quando a silagem de milho foi a única fonte de forragem da dieta. Smith et al. (1993) observou um pequeno efeito negativo quando o feno de alfafa foi na proporção de $12,5 \%$ da MS da dieta, e não observou nem um efeito quando o feno de alfafa foi na proporção de $25 \%$ da MS da dieta, enquanto que Chik et al. (1987) observou um efeito benéfico na composição de sólidos totais do leite quando toda a forragem foi feno de alfafa (40\% da MS). Já Adans (1993) encontrou um efeito negativo na composição de sólidos totais do leite quando o caroço de algodão foi acrescentado à dieta em todas as combinações de forragem testadas. A inclusão de caroço de algodão em dietas contendo parcialmente ou totalmente feno de alfafa como volumoso, teve uma eficiente associação em outros experimentos, porem nesse estudo aparentemente não foi incluído em quantidades suficientes $(11,25 \% \mathrm{MS})$ para ter um efeito benéfico, da mesma forma. Smith et al. (1993) também não observou efeito benéfico com inclusão de $12,5 \%$ de feno de alfafa. Adams (1993) observou que a substituição de parte da silagem de milho pôr casca de semente de algodão foi benéfico. Estes trabalhos sugeriram que os efeitos negativos do caroço de algodão estão associados com os componentes do caroço de algodão e não com componentes da casca, que geralmente é benéfico para a ingestão de MS e produção de leite (ADAMS, 1993; Morales, 1989). 
A recomendação minima de fibra para vacas leiteiras de alta produção, convencionalmente é em torno de $26-28 \%$ de FDN na dieta total e que $75 \%$ deste FDN seja provenientes da fonte de volumoso. Quando se adicionou caroço de algodão para substituir o FDN proveniente da forragem (feno de alfafa), os autores encontraram uma diminuição para o tratamento com feno de alfafa como maior contribuinte do FDN, na produção de leite, concentração de proteína do leite, produção de proteína ( Clark \& Armentano, 1993).

Staples er al. (1991) revisando várias trabalhos com caroço de algodão concluiram que, quando silagem de milho foi a base da forragem, o uso de caroço de algodão suprimiu a síntese de gordura do leite, um fato que não foi encontrado quando se utiliza feno de alfafa. Smith et al. (1992), também relataram que a diminuição da gordura do leite quando se utiliza caroço de algodão em dietas com silagem de milho, pode ser atenuada com a adição de feno de alfafa. Já Clark \& Armentano (1993) não encontraram diferença entre o feno de alfafa e o caroço de algodão quando a dieta tinha feno de alfafa com base do volumoso, e o caroço de algodão foi acrescentado para substituir parte do FDN da dieta.

Clark et al. (1993) utilizando caroço de algodão como fonte de fibra de origem não forrageira comparado com feno de alfafa como fonte de fibra de origem forrageira, observaram uma maior produção de leite, porcentagem de proteina do leite, produção de proteina do leite e ingestão de matéria seca para os tratamentos que receberam fontes de fibra de origem não forrageiras. 


\section{MATERIAL E MÉTODOS}

\subsection{Animais e instalações experimentais}

Foram utilizadas cinco vacas da raça Holandesa preto e branco (HPB) fistuladas com cânula no rúmen e no duodeno proximal. Todas elas estavam no final da sua segunda lactação com uma produção média diária de 15 quilos de leite. As vacas foram submetidas à cirurgia para colocação de cânulas no Departamento de Produção Animal da ESALQ - USP.

O experimento, foi conduzido nas instalações do Centro de Pesquisa em Nutrição Animal do Departamento de Produção Animal/Ruminantes da ESALQ/USP, onde os animais foram alojados em um galpão coberto, com ventiladores e baias individuaisdo tipo "tie stall" com dimensões 2,5×1,10 m contendo comedouros individuais e bebedouros automáticos a cada 2 baias; o piso foi revestido com um tapete de borracha, e esse coberto com uma camada de maravalha de madeira, trocada diariamente. 


\subsection{Tratamentos}

As dietas foram formuladas para serem isoprotéicas contendo silagem de milho, milho moído fino, farelo de soja, uréia, suplemento mineral e vitamínico e niveis crescentes de caroço de algodão (CA). Todas as dietas tiveram a mesma proporção de volumoso:concentrado ( $60 \%$ volumoso e $40 \%$ concentrado). Os níveis de caroço de algodão foram determinantes dos tratamentos. Os tratamentos testados foram: 1) dieta controle sem CA (T0), 6\% de CA (T6), 12\% de CA (T12), $18 \%$ de CA (T18) e $24 \%$ de CA (T24). A composição e proporção das dietas estão demostradas nas Tabelas 1 e 2 respectivamente.

Tabela 1 - Proporção dos componentes das dietas.

\begin{tabular}{lrrrrr}
\hline \multirow{2}{*}{ Ingredientes } & \multicolumn{5}{c}{ Tratamentos $^{1}$} \\
\cline { 2 - 6 } & \multicolumn{1}{c}{ T0 } & T6 & \multicolumn{1}{c}{ T12 } & T18 & \multicolumn{1}{c}{ T24 } \\
\hline \multirow{2}{*}{ Silagem de Milho } & 59,96 & 60,00 & 59,94 & 59,67 & 59,55 \\
Farelo de Soja & 16,61 & 14,83 & 12,70 & 10,77 & 8,21 \\
Milho Moído & 21,06 & 16,17 & 12,36 & 8,80 & 5,57 \\
Uréia & 0,76 & 0,77 & 0,77 & 0,77 & 0,77 \\
Premix & 1,61 & 2,30 & 2,30 & 2,11 & 1,97 \\
Caroço de Algodão & & 5,93 & 11,93 & 17,89 & 23,94 \\
\hline
\end{tabular}


Tabela 2 - Composição das dietas (\%MS).

Tratamentos

Nutrientes

\begin{tabular}{lrrrrr}
\cline { 2 - 6 } \multicolumn{1}{c}{ Nutrientes } & \multicolumn{1}{c}{ T0 } & \multicolumn{1}{c}{ T6 } & \multicolumn{1}{c}{ T12 } & \multicolumn{1}{c}{ T18 } & \multicolumn{1}{c}{ T24 } \\
\hline PB\% & 17,87 & 17,94 & 17,44 & 17,01 & 16,03 \\
FDN \% & 33,36 & 35,36 & 37,09 & 39,55 & 41,79 \\
FDA \% & 20,67 & 22,02 & 24,00 & 26,17 & 28,22 \\
EE \% & 2,67 & 3,59 & 4,53 & 5,85 & 6,90 \\
EB (Kcal/kg MS) & 4207,4 & 4251,6 & 4334,5 & 4372,1 & 4423,9
\end{tabular}

Porcentagem de caroço de algodão nas dietas

O alimento concentrado foi misturado previamente para cada período em um misturador vertical (marca Lucato, capacidade $500 \mathrm{~kg}$ ). No momento do fornecimento do alimento para os animais pesava-se a silagem de milho e o concentrado separadamente, os quais eram posteriormente misturados no cocho, objetivando a obtenção de uma ração completa. O fornecimento do alimento foi feito duas vezes por dia (6:00 e 18:00 horas), permitindo uma sobra de 5 a $10 \%$ que era retirada e pesada diariamente.

\subsection{Período experimental}

O experimento foi realizado no primeiro semestre do ano de $1998 \mathrm{com}$ duração de 90 dias. Utilizou-se um quadrado latino $5 \times 5$ com 5 sub-períodos de 18 dias cada, sendo 14 dias para adaptação e 4 dias de período de coleta. Todos os animais eram soltos diariamente durante o periodo de adaptação por uma hora em uma área de terra próxima ao galpão para se exercitarem e para se fazer a limpeza das instalações. 


\subsection{Adição do óxido de cromo (marcador externo)}

O óxido de cromo foi utilizado como marcador externo. Envelopes de papel sulfite branco, contendo a quantidade de $10 \mathrm{~g}$ de marcador foram introduzidos no rúmen através da cânula ruminal às 8:00 e às 20:00 horas totalizando $20 \mathrm{~g}$ por dia/animal, durante 10 dias consecutivos, iniciando-se no $9^{\circ}$ dia de cada sub-período até o último.

3.5 Coleta de dados referentes ao alimento oferecido e recusado para avaliação de consumo de matéria seca

O alimento oferecido e o recusado eram pesados diariamente para determinação do consumo de matéria seca (MS) por animal/dia, durante os quatro dias do período de coleta, durante os quatro últimos dias de cada sub-período, antes do fornecimento das dietas, as sobras de alimento eram amostradas e compostas por vaca e período na quantidade de $500 \mathrm{~g} / \mathrm{dia}$ totalizado $2 \mathrm{~kg}$ de amostra por sub-período. O alimento oferecido foi coletado na mesma quantidade do recusado, mas a silagem era coletada separadamente do concentrado. As amostras foram conservadas congeladas a $-20^{\circ} \mathrm{C}$ e posteriormente foram descongeladas e secas em estufas de ventilação forçada $\left(55-60^{\circ} \mathrm{C}\right)$ por 72 horas para determinação de matéria seca de acordo com A. O. A. C. (1990).

As amostras de oferecido e recusado depois de secas foram moídas em um moinho tipo Wiley providos de peneiras de um $\mathrm{mm}$ e analisadas para matéria seca $\left(105^{\circ} \mathrm{C}\right.$ durante $\left.15 \mathrm{~h}\right)$, matéria orgânica $(\mathrm{MO})$, extrato etéreo $(\mathrm{EE})$ e proteina bruta (PB) de acordo com a A. O. A. C. (1990), e fibra em detergente neutro (FDN) e fibra detergente ácido (FDA) de acordo com Van Soest (1991). 
3.6 Coleta de fluído ruminal para determinação de ácidos graxos voláteis (AGVs) e pH ruminal

As amostras de fluido ruminal foram coletadas no último dia de coleta de cada sub-período, com intervalos de 2 horas entre cada coleta. Os tempos de coleta foram determinados obedecendo os horários da alimentação, sendo que o tempo zero foi antes do fornecimento da dieta pela manhã e o tempo 10 era duas horas antes do fornecimento da dieta no dia seguinte. Foram coletadas quatros amostras do conteúdo ruminal sendo essas feitas em pontos diferentes do rúmen $\mathrm{e}$ depois filtrada em duas camadas de tecido de algodão (fraldas) obtendo-se desta forma aproximadamente $200 \mathrm{ml}$ de filtrado de rúmen. Depois da filtragem o conteúdo foi dividido em 2 porções, sendo a primeira utilizada para aferir $\mathrm{opH}$ ruminal através da leitura direta em um potenciômetro digital da Digimed, modelo TE-902; a segunda sofreu um acréscimo de solução de ácido cloridrico e depois foi congelada à $-10^{\circ} \mathrm{C}$, para posteriormente ser analisada para ácidos graxos voláteis.

As amostras de fluído ruminal para determinação de AGVs foram descongeladas, centrifugadas a $11.000 \mathrm{~g}$ à $4^{\circ} \mathrm{C}$, durante 20 minutos e uma porção de $4 \mathrm{ml}$ desse centrifugado foi utilizado para análise de AGVs de acordo com Palmiquist \& Conrad (1971), utilizando um cromátografo líquido gasoso (CLG) Hewlett Packard 5890, series II ( Jewlett - Pacard Company, Avondale, PA). As temperaturas de injetor, detector e coluna foram 150,190 e $115^{\circ} \mathrm{C}$, respectivamente. 


\subsection{Coleta de fezes para determinação da digestibilidade aparente do trato digestivo total.}

Foram coletadas amostras de fezes, da porção final do reto, nos últimos 4 dias de cada sub-período à cada 8 horas, adiantando duas horas por dia, de maneira que se obtivesse uma amostra a cada duas horas no intervalo de 24 horas depois do término dos 4 dias de coleta. As amostras foram compostas por vaca e periodo, e congeladas a $-10^{\circ}$ C. Posteriormente essas amostras foram descongeladas homogeneizadas e coletado uma porção de $200 \mathrm{~g}$ do material. Essa porção foi seca em estufas de ventilação forçada $\left(55-60^{\circ} \mathrm{C}\right)$ por 72 horas, depois moída em moinho do tipo Wiley provido de peneiras de um $\mathrm{mm}$ para determinação do cromo segundo Fenton \& Fenton (1979) com leitura em espectrofotômetro de absorção atômica. A determinação da matéria seca $\left(105^{\circ} \mathrm{C}\right.$ durante $\left.15 \mathrm{~h}\right)$, matéria orgânica (MO) e proteína bruta (PB) de acordo com a A. O. A. C. (1990), a fibra em detergente neutro (FDN) e fibra em detergente ácido (FDA) foi de acordo com Van Soest (1991). O EE nas fezes foi determinado com éter de petróleo adicionado de $10 \%$ de ácido acético, para liberar os ácidos graxos (Mattos \& Palmquist, 1974)

A digestibilidade aparente (D) no trato digestivo total da MS e demais nutrientes da dieta foi calculada utilizando-se os valores de cromo recuperado e cromo oferecido a cada animal pela fórmula:

$$
\left.D(\%)=100-100 \times \frac{\% \text { cromo no alimento }}{\% \text { cromo nas fezes }} \times \frac{\% \text { do nutriente nas fezes }}{\% \text { do nutriente no alimento }}\right)
$$




\subsection{Coleta de conteúdo duodenal para determinação da digestilidade de nutrientes e fluxo de proteína microbiana}

As amostras de duodeno foram coletadas na quantidade de $250 \mathrm{ml}$ para determinação da digestibilidade e de $500 \mathrm{ml}$ para determinação da composição bacteriana. As duas amostras eram coletadas separadamente e com o cuidado de sempre desprezar os primeiros jatos de conteúdo que saiam pela cânula, e o possivel extravasamento do conteúdo do recipiente de coleta. Essas práticas são utilizadas para que não se tenha um conteúdo coletado já parado na cânula desde a ultima coleta, e também para que se despreze porções não representativas do conteúdo duodenal.

A amostragem para determinação da digestibilidade foi feita a cada quatro horas, adiantando uma hora por dia, durante os 4 dias de coleta de cada subperíodo Essas foram compostas por vaca e período e depois congeladas à $-10^{\circ} \mathrm{C}$. Quando descongeladas, as amostras foram homogeneizadas e retirado uma porção de $200 \mathrm{ml}$ para secagem em estufa de ventilação forçada $\left(55-60^{\circ} \mathrm{C}\right)$ por 72 horas, depois moídas em um moinho tipo Wiley provido de peneiras de um $\mathrm{mm}$. As amostra foram então analisadas para cromo segundo Fenton \& Fenton (1979) utilizando um espectrofotômetro de absorção atômica Também foi determinada a matéria seca $\left(105^{\circ} \mathrm{C}\right.$ durante $\left.15 \mathrm{~h}\right)$, matéria orgânica $(\mathrm{MO})$, extrato etéreo $(\mathrm{EE})$ e proteína bruta (PB) de acordo com a A. O. A. C. (1990), e fibra em detergente neutro (FDN) e fibra em detergente ácido (FDA) de acordo com Van Soest (1991).

As amostras de conteúdo duodenal destinadas a composição bacteriana, foram coletadas a cada quatro horas durante 24 horas, totalizando três litros por período. Depois de coletadas as amostras foram batidas em liquidificador durante 30 segundo, coadas em pano de algodão (fralda) dobrado quatro vezes e resfriadas até o final da cada período de coleta e posteriormente congeladas para manipulação futura. Depois de descongeladas essas amostras forma centrifugadas em baixa rotação $(2.000 \mathrm{~g} / 15 \mathrm{~min})$ para retirar a parte sólida ainda existente na 
amostra, recuperando o sobrenadante. Uma segunda centrifugação foi feita em alta rotação (18.000 $\mathrm{g} / 15 \mathrm{~min})$ desprezando o sobrenadante e recuperando o precipitado, que foi congelado à $-10^{\circ} \mathrm{C}$.

A recuperação do cromo para determinação das digestibilidades ruminais não teve êxito, impossibilitando desta forma a utilização desses dados para determinação de digestibilidade ruminal aparente e produção de proteína microbiana.

\subsection{Determinação da composição e da produção do leite}

A ordenha foi realizada mecanicamente duas vezes ao dia (8:00 e 18:00 horas) com um sistema de balde ao pé. O leite foi pesado e amostrado diariamente nas duas ordenhas nos 4 dias de coleta de cada sub-período para avaliação de produção e composição do leite. As amostras de leite foram compostas por dia e por vaca e conservadas com 2-bromo-2-nitropropano-1-3-diol sob refrigeração $\left(6^{\circ}\right.$ C) para posterior determinação de proteína e gordura por leitura de absorção de infravermelho próximo, utilizando um equipamento Blentley 2000 (Blentley ,1995) do Laboratório de Análise de Leite / Departamento de Produção Animal da ESALQ/USP.

\subsection{Digestibilidade in situ}

As amostras da dieta (em torno de $5,5 \mathrm{~g}$ ) foram moídas em peneira de $2 \mathrm{~mm}$, pesadas e colocadas nos sacos de poliéster de $10 \times 15 \mathrm{~cm}$ com porosidade média de $45 \mu \mathrm{m}$. Os sacos foram introduzidos no rúmen em duplicatas, todos em um mesmo horário e retirados gradativamente respeitando os seguintes horários: 0 , 
$2,4,8,12,24,48$ e 72 horas após a incubação ruminal. Cada animal estava recebendo a mesma dieta, que foi colocada nos sacos de poliéster. Os sacos depois de recolhidos foram enxaguados imediatamente com água fria.

Quantidades residuais de matéria orgânica e a porcentagem de matéria seca foram determinadas após os sacos terem sido secos por 48 horas em estufas a $60^{\circ} \mathrm{C}$ com ventilação forçada.

Os dados das amostras incubadas foram processados utilizando 0 "software Fit Curve" desenvolvido pelo Rowett Research Institute, Aberdeen, Escócia, que fornece dentre outras informações, os parâmetros do modelo de degradabilidade ruminal de Orskov \& McDonald (1979). A degradabilidade potencial in situ da matéria seca (MS) foi calculada de acordo com a equação:

$\mathrm{dg}=\mathrm{a}+\mathrm{b}\left(1-\mathrm{e}^{-\mathrm{ct}}\right)$

Sendo:

$\mathrm{dg}=\mathrm{a}$ degradabilidade estimada;

$a$ = fração rapidamente solúvel em água;

$b=$ fração insolủvel em água, mas potencialmente degradável;

$c=$ taxa de degradação da fração $b$;

$e=$ logaritmo natural $e$

$a+b=$ potencial de degradabilidade.

A degradabilidade efetiva foi calculada pela equação de Orskov \& McDonald (1979):

$$
p=a+b c^{-c+r} \text {. }
$$

Onde: $r$ é a taxa de passagem.

Para o cálculo da degradabilidade efetiva, deve-se considerar a taxa de passagem de alimentos pelo rúmen. O ARC (1993) sugere valores de 2,5 e $8 \% / h$ para consumo menor, igual e maior que mantença respectivamente. 


\subsection{Análise Estatística}

O delineamento experimental utilizado foi um Quadrado Latino $5 \times 5$ (cinco animais e cinco períodos).

Os dados obtidos foram avaliados pelo procedimento GLM ( generalized linear models) do programa estatístico SAS (1991), utilizando o seguinte modelo estatístico:

$Y_{i j k}=M+A_{l}+P_{m}+S_{j}+E_{i j k}$

Onde:

$M=$ Média geral

$A_{1}=$ Efeito de animal

$P_{m}=$ Efeito de período

$S_{\mathrm{j}}=$ Efeito dos níveis de caroço de algodão

$E_{i j k}=$ Efeito aleatório

O quadro de análise de variância está apresentado na Tabela 3.

Tabela 3 Análise de variância para digestibilidade e produção

\begin{tabular}{lc}
\hline Causa de Variação & Graus de Liberdade \\
\hline Animal & 4 \\
Período & 4 \\
Níveis de Caroço de Algodão & 4 \\
Resíduo & 12 \\
\hline Total & 24 \\
\hline
\end{tabular}

O $\mathrm{pH}$ e AGVs foram analisadas estatisticamente como parcela subdivididas no tempo. Os efeitos de tratamento, animal e periodo foram testados com relação às parcelas. $A$ interação horário de coleta $X$ tratamentos foi testada com relação à sub-parcelas. 
Foi considerado $5 \% \quad(P<0,05)$ como nível de significância para probabilidade do teste $\mathrm{F}$ na análise de variância. Para as variáveis que obtiveram respostas significativas, utilizou-se o comando LSMEANS para verificar as diferenças entre os tratamentos para as diversas variáveis. As médias das tabelas foram obtidas pelo comando LSMEANS para as parcelas e sub-parcelas. Foi aplicado um contraste polinomial de níveis equidistantes para os tratamentos. 


\section{RESULTADOS E DISCUSSÃO}

\subsection{Consumo de matéria seca e produção do leite}

O consumo de matéria seca (CMS) está apresentado na Tabela 4. Houve uma tendência $(P<0,078)$ de efeito linear com redução no CMS à medida que a inclusão de CA na dieta superou $12 \%$ da MS da dieta. Simas (1995), quando adicionou gordura protegida a dieta de vacas leiteira relata que provavelmente essa tendência é proveniente do estágio de lactação das vacas, que era muito avançado, essa característica provavelmente explica essa tendência encontrada nesse trabalho, pois os animais encontravam-se em estágio avançado da lactação. Trabalhos utilizando $\mathrm{CA}$, caroço de algodão processado ou outra fonte de gordura (Hawkins et al., 1985; Mohamed et al., 1988; Lanham et al., 1992) demostraram uma redução no consumo de MS em quilos por dia. Entretanto, Smith et al. (1981) não encontrou efeito no consumo de matéria seca quando utilizaram níveis $(0,5,15,25 \%)$ de $C A$, contendo silagem de milho como volumoso, na dieta de vacas leiteiras, esses resultado também foram encontrados por outros autores (DePeter et al., 1985; Horner et al., 1988; Wu et al., 1993; Wu et al., 1994; Villela et al., 1996). 
As produções médias de leite, composição do leite e eficiência alimentar nos tratamentos estão apresentadas na Tabela 4.

Tabela 4. - Efeito do caroço de algodão (CA) no consumo de matéria seca e desempenho de vacas leiteiras.

\begin{tabular}{|c|c|c|c|c|c|c|c|c|}
\hline \multirow[t]{2}{*}{ Itens } & \multicolumn{5}{|c|}{ Tratamentos ${ }^{\top}$} & \multicolumn{3}{|c|}{ Efeito } \\
\hline & T0 & T6 & $T 12$ & T18 & T24 & EPM & Linear & Quad. \\
\hline CMS Kg/dia & 16,91 & 17,13 & 16,98 & 16,06 & 15,34 & 0,67 & 0,078 & 0,332 \\
\hline Leite, $\mathrm{Kg} / \mathrm{dia}$ & 16,64 & 17,61 & 17,12 & 16,90 & 14,66 & 0,74 & 0,070 & 0,047 \\
\hline PLCG $3,5 \% \mathrm{Kg} / \mathrm{dia}$ & 16,41 & 17,12 & 17,28 & 17,59 & 15,59 & 0,79 & 0,651 & 0,100 \\
\hline EA (PLCG/CMS) & 0,99 & 1,00 & 1,02 & 1,10 & 0,99 & 0,05 & 0,556 & 0,404 \\
\hline \multicolumn{9}{|l|}{ Gordura do Leite } \\
\hline$\%$ & 3,45 & 3,31 & 3,55 & 3,81 & 4,03 & 0,10 & 0,000 & 0,078 \\
\hline g/dia & 566,4 & 584,8 & 607,6 & 632,7 & 569,5 & 30,69 & 0,588 & 0,186 \\
\hline \multicolumn{9}{|l|}{ Proteína do Leite } \\
\hline$\%$ & 3,20 & 3,34 & 3,20 & 3,12 & 3,24 & 0,08 & 0,60 & 0,98 \\
\hline g/dia & 531,4 & 587,6 & 624,0 & 527,1 & 461,7 & 38,82 & 0,12 & 0,02 \\
\hline
\end{tabular}

Houve um efeito quadrático na produção de leite $(P<0,05)$ com 0 aumento de CA na dieta; e uma tendência $(P<0,1)$ para produção de leite corrigida para $3,5 \%$ de gordura. Resultados similares foram observados por Simas (1995) que observou um aumento na produção de leite e produção de leite corrigida para gordura, quando suplementou vacas com gordura protegida. Entretanto, outros autores têm mostrado que o aumento do nivel de gordura na dieta, não altera a produção de leite corrigida para gordura (Palmquist \& Corand, 1978; Grant \& Weidner, 1992; Lu, 1993; Pires et al., 1996; Villela et al., 1996).

A produção de gordura do leite $(g / d)$ não foi alterada $(P>0,05)$ com a adição de caroço de algodão na dieta, já a concentração de gordura (\%) aumentou linearmente $(P<0,05$; Figura 2). Alterações na porcentagem de gordura do leite não foram observadas em outros trabalhos ( Palmquist e Conrad, 1978; Bernard, 1990; Wu et al., 1994; Rabelo, 1995; Pereira et al., 1998;). A suplementação com 
gordura modifica o perfil de ácido graxos do leite, ocorrendo uma redução nos ácidos graxos de cadeia curta, e um aumento nos de cadeia longa em vacas ( Macleod et al., 1972; Smith et al., 1981; Mielk \& Schingoethe, 1981; Mohamed et al., 1988). Esses trabalhos indicaram que a glândula mamária incorpora ácidos graxos da dieta no leite o que aumentaria a produção de gordura no leite, mas isto não ocorre sempre, já que a suplementação com gordura reduz a sintese de ácidos graxos na glândula mamária. Com pouca consolidação, a teoria mais recente sobre a diminuição da gordura do leite é a dos ácidos graxos trans. Segundo essa hipótese estes ácidos provavelmente inibem a ação da enzima acetil CoA carboxilase a qual é necessária na síntese de ácidos graxos na glândula mamária. Os fatores que afetam o acúmulo de ácidos graxos trans no rúmen são fontes de ácidos graxos poliinsaturados na dieta e $\mathrm{pH}$ ruminal baixo (Erdman, 1999). A suplementação de gordura pode aumentar a gordura do leite ou até diminuir, dependendo da fonte de gordura utilizada (grau de insaturação) e do manejo alimentar (acidose).

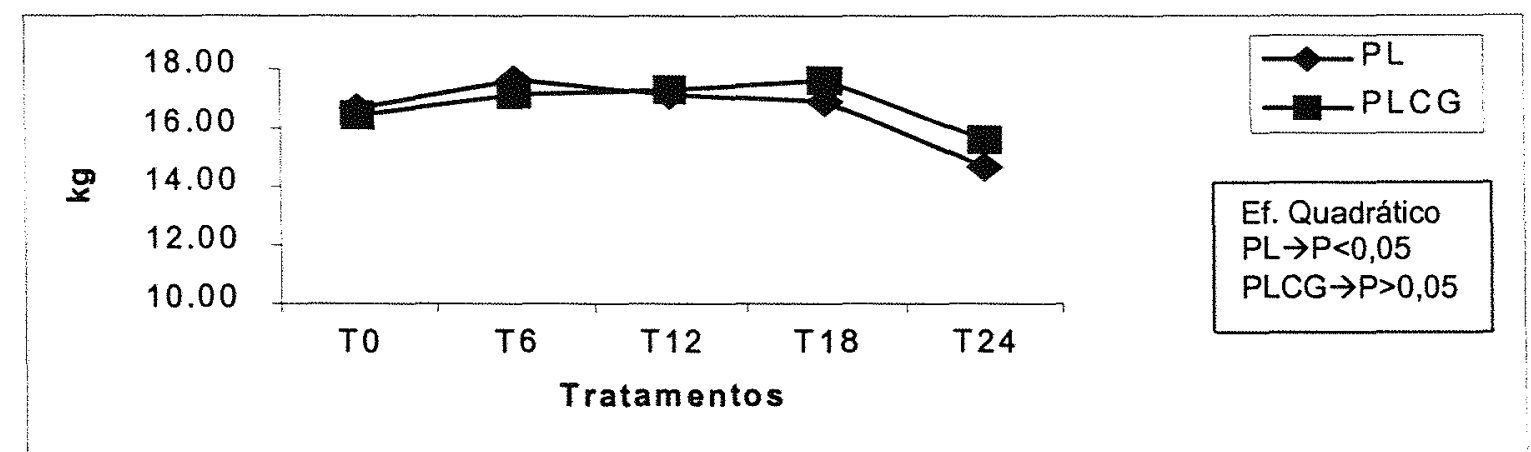

Figura 1. Efeito de níveis de caroço de algodão na produção de leite (PL) produção de leite corrigida para 3,5\% de gordura (PLCG) em Kg/d. 

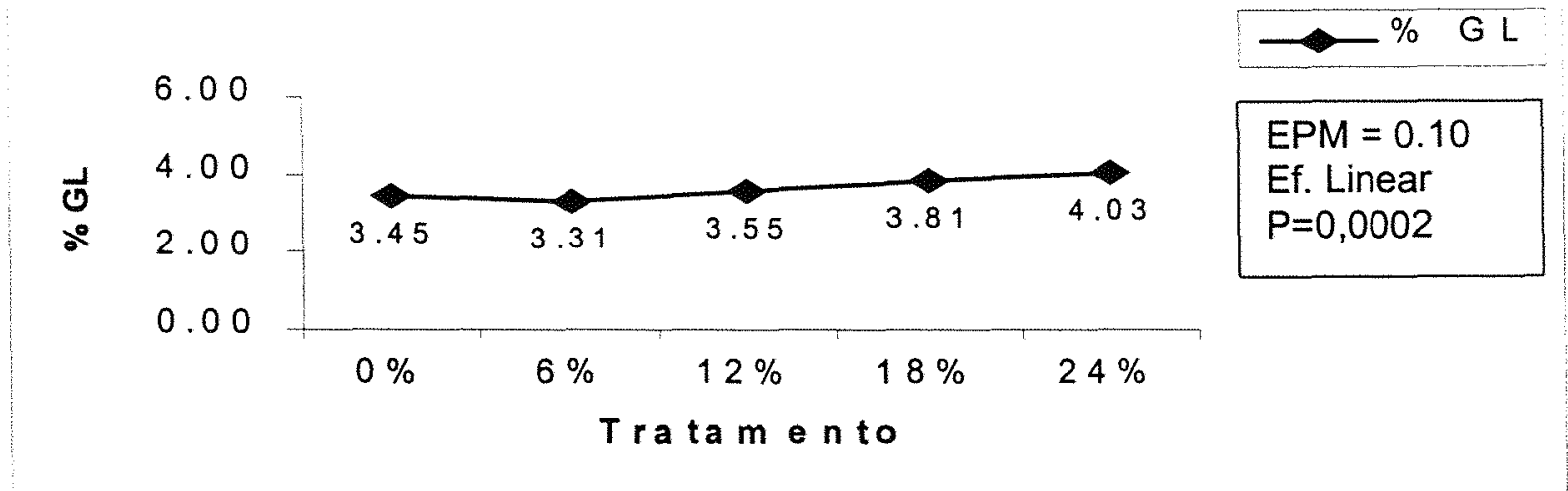

Figura 2. Efeito de níveis de caroço de algodão na percentagem de gordura do leite.

O teor de proteína do leite não sofreu alterações com a adição de caroço de algodão na dieta $(P>0,05)$, já a produção de proteína em g/d teve um comportamento quadrático. Outros autores (Rabelo, 1995; Pereira, et al., 1998), também encontram alterações no teor de proteína do leite. Entretanto Wu \& Huber (1994) revisando a literatura, concluíram que a suplementação com gordura está associada a uma redução na proteína do leite. $O$ efeito quadrático na produção de proteína ( Figura 4) pode ter sido devido à maior eficiência na síntese de proteína do leite por unidade de PB consumida da dieta, associado a uma redução no consumo de MS (Tabela 4). DePeter (1985) obteve um redução na produção de proteína do leite quando aumento a concentração de caroço de algodão da dieta. Essa mesma resposta foi encontrada por outros autores quando adicionaram outra fonte de gordura a dieta (Mohamed et al., 1988; Hawkins et al., 1985; Wu et al., 1994; Bitman et al., 1996) 


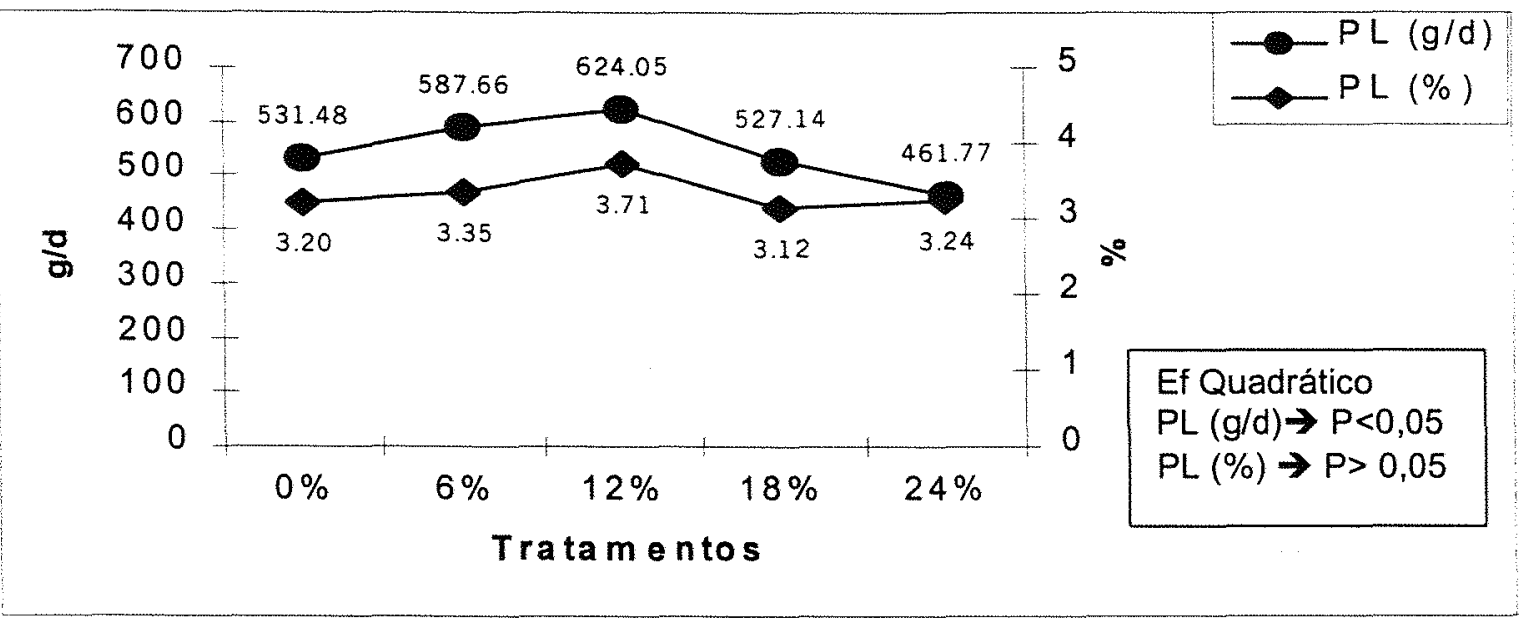

Figura 3. Efeito da níveis de caroço de algodão na proteína do leite em gramas por dia e em porcentagem.

A eficiência alimentar não sofreu interferência com a adição de caroço de algodão na dieta $(P>0,05)$. Essa mesma resposta foi encontrada por Pires et al. (1997) adicionando fontes de gordura à dieta de vacas leiteiras.

4.2 Consumo e digestibilidade dos nutrientes no trato digestivo total.

\subsubsection{Matéria Seca e Matéria Orgânica}

O consumo médio e a digestibilidade aparente da matéria seca e matéria orgânica no trato digestivo total, estão apresentadas na Tabela 5. 
Tabela 5. Efeito do caroço de algodão no CMS e na digestibilidade dos nutrientes

\begin{tabular}{|c|c|c|c|c|c|c|c|c|}
\hline \multirow[b]{2}{*}{ Itens } & \multicolumn{5}{|c|}{ Tratamentos } & \multicolumn{3}{|c|}{ Efeito } \\
\hline & T0 & T6 & T12 & T18 & T24 & EPM & Linear & Quad. \\
\hline CMS, kg/d & 16,91 & 17,13 & 16,98 & 16,06 & 15,39 & 0,67 & 0,07 & 0,33 \\
\hline DMSTT, $\mathrm{kg} / \mathrm{d}$ & 11,47 & 11,85 & 11,01 & 10,47 & 9,93 & 0,55 & 0,02 & 0,47 \\
\hline DMSTT, \% & 67,54 & 68,90 & 65,32 & 64,90 & 63,18 & 1,26 & 0,00 & 0,53 \\
\hline $\mathrm{CMO}, \mathrm{kg} / \mathrm{d}$ & 15,11 & 15,21 & 15,05 & 14,33 & 13,81 & 0,59 & 0,08 & 0,43 \\
\hline DMOTT, $\mathrm{kg} / \mathrm{d}$ & 12,01 & 12,34 & 11,63 & 11,09 & 10,70 & 0,43 & 0,04 & 0,54 \\
\hline DMOTT, \% & 70,95 & 71,75 & 68,91 & 68,89 & 69,05 & 1,07 & 0,07 & 0,71 \\
\hline
\end{tabular}

Houve tendência de efeito linear de redução no CMS e CMO com a adição de caroço de algodão a dieta de vacas em lactação Pires et al. (1997) também encontrou uma diminuição no consumo de matéria orgânica quando acrescentou caroço de algodão à dieta.

Horner et al. (1988), utilizando $15 \%$ de caroço de algodão da dieta não observaram diferença na digestibilidade aparente da matéria seca. Mohamed et al. (1988) não encontraram diferença na digestibilidade da matéria seca quando acrescentaram, caroço de algodão à dieta. Entretanto, Wu et al (1994) observaram que a digestibilidade aparente da matéria orgânica tende a ser menor $(P<0,13)$.

Palmquist (1991) propôs uma redução de 2,2\% na digestibilidade da MS para cada $100 \mathrm{~g}$ de gordura consumida, e também sugeriu que esta redução da digestibilidade ocorre linearmente com o aumento da gordura na dieta de vacas em lactação. Jenkins \& Jenny (1989) consideraram que a gordura suplementar geralmente diminui e em alguns casos tem efeito mínimo sobre a digestibilidade da matéria seca. A digestibilidade aparente da matéria seca do tratamento $24 \%$ CA diminuiu $4,36 \%$, quando comparado com o tratamento $0 \%$. O consumo de 
gordura foi de $0,61 \mathrm{~g}$ superior que o tratamento $24 \%$, ocorrendo uma redução na digestibilidade aparente da matéria seca de 1,06\%/100g de gordura consumida, inferior a proposta feita por Palmquist (1991).

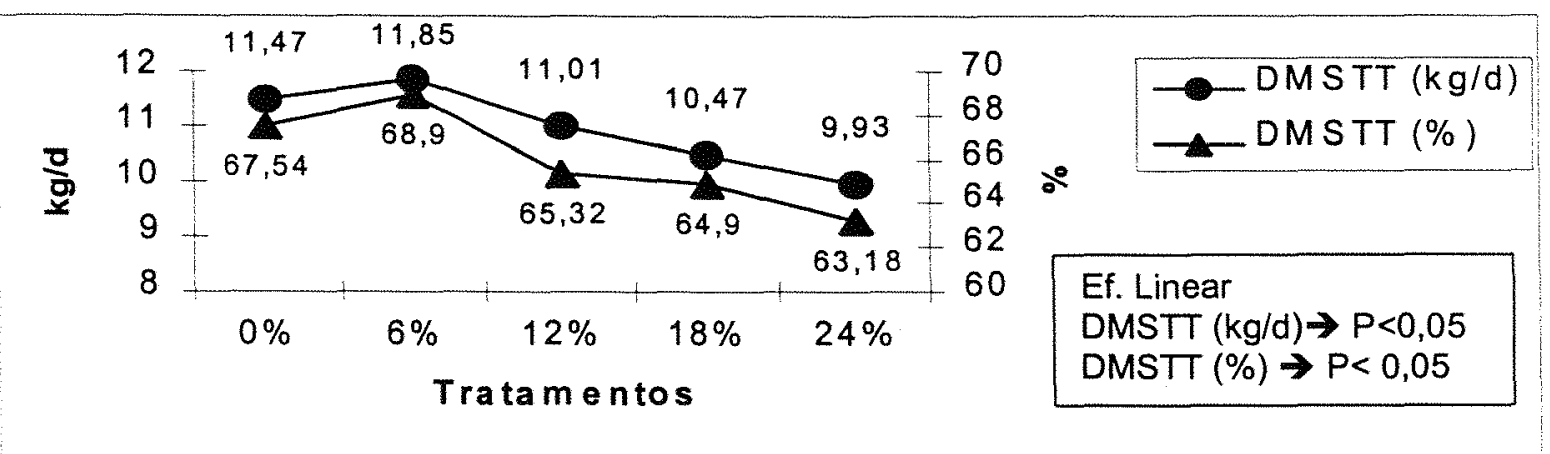

Figura 4 Efeito de niveis de caroço de algodão na digestibilidade aparente da matéria seca no trato digestivo total.

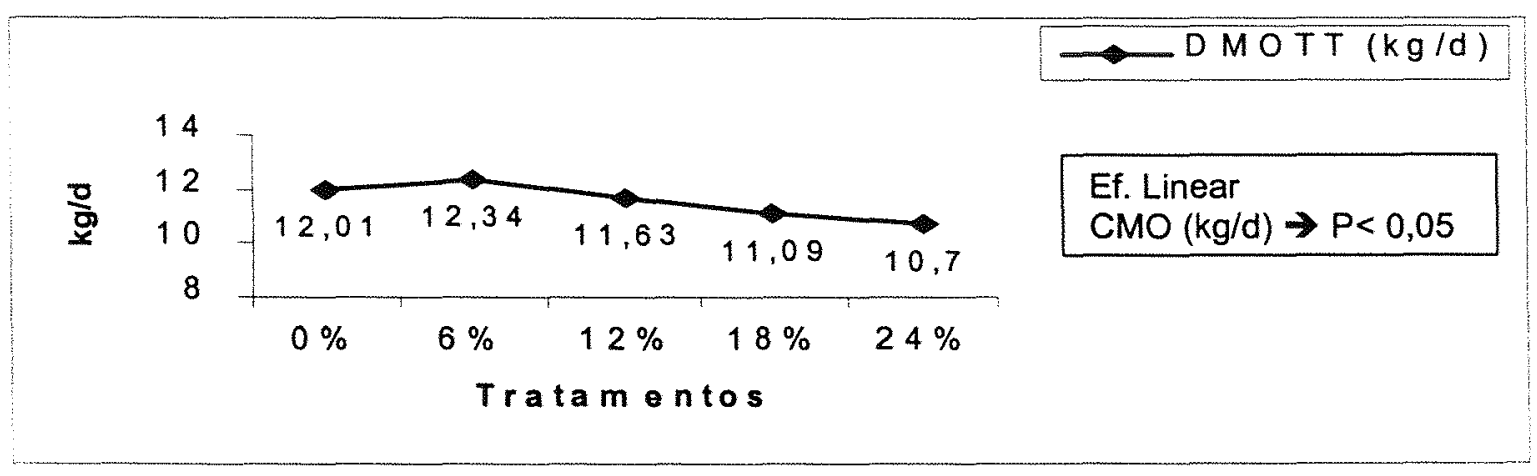

Figura 5. Efeito de níveis de caroço de algodão no consumo de matéria orgânica. 


\subsubsection{Fibra em detergente neutro e fibra em detergente ácido.}

O consumo médio e a digestibilidade aparente da fibra em detergente neutro e fibra em detergente ácido no trato digestivo total, estão apresentados na Tabela 6.

Houve uma tendência $(P<0,08)$ linear de aumento no FDN com doses crescentes de CA na dieta e um efeito linear crescente no CFDA. Esse fato ocorreu uma vez que as dietas apresentavam níveis crescente de FDN e FDA na dieta (Tabela 2). Pires et al. (1997) encontraram um aumento no consumo de FDN quando se acrescentaram caroço de algodão à dieta.

Tabela 6. Efeito da adição de caroço de algodão no consumo e digestibilidade aparente da fibra em detergente neutro (FDN) e fibra em detergente ácido (FDA) no trato digestivo total.

\begin{tabular}{|c|c|c|c|c|c|c|c|c|}
\hline \multirow[b]{2}{*}{ Itens } & \multicolumn{5}{|c|}{ Tratamentos ${ }^{T}$} & \multicolumn{3}{|c|}{ Efeito } \\
\hline & TO & T6 & $\mathrm{T} 12$ & T18 & T24 & EPM & Linear & Quad. \\
\hline CFDN, $\mathrm{kg} / \mathrm{d}$ & 5,85 & 6,05 & 6,35 & 6,37 & 6,48 & 0,26 & 0,08 & 0,65 \\
\hline DFDNTT, kg/d & 3,43 & 3,52 & 3,53 & 3,51 & 3,69 & 0,19 & 0,40 & 0,82 \\
\hline DFDNTT, \% & 56,08 & 57,67 & 55,72 & 54,55 & 55,90 & 1,89 & 0,57 & 0,96 \\
\hline CFDA, kg/d & 3,52 & 3,77 & 4,11 & 4,20 & 4,34 & 0,16 & 0,00 & 0,48 \\
\hline DFDATT, $\mathrm{kg} / \mathrm{d}$ & 2,05 & 2,22 & 2,31 & 2,24 & 2,34 & 0,14 & 0,15 & 0,35 \\
\hline DFDATT, \% & 56.44 & 58,73 & 56,08 & 52,53 & 51,02 & 2,37 & 0,04 & 0,47 \\
\hline
\end{tabular}

O coeficiente de digestibilidade aparente no trato total de FDN não sofreu influência com a adição de caroço de algodão a dieta. Esse mesmo resultado foi encontrado por Wu et al. (1993) quando acrescentaram fontes de 
gordura a dieta. Outros trabalhos (Smith et al., 1981; Wu et al., 1994) também não observaram influência do caroço de algodão na digestibilidade do FDN.

Devendra \& Lewis (1974) sugerem que alguns mecanismos podem atuar no rúmen, com a adição de gordura na dieta, reduzindo a digestibilidade da porção FDN da dieta. Palmquist \& Jenkins (1980), concluiram que muitos dados sugerem a inibição da digestibilidade da porção fibrosa por uma ação inibitória da gordura sobre as bactérias ruminais.

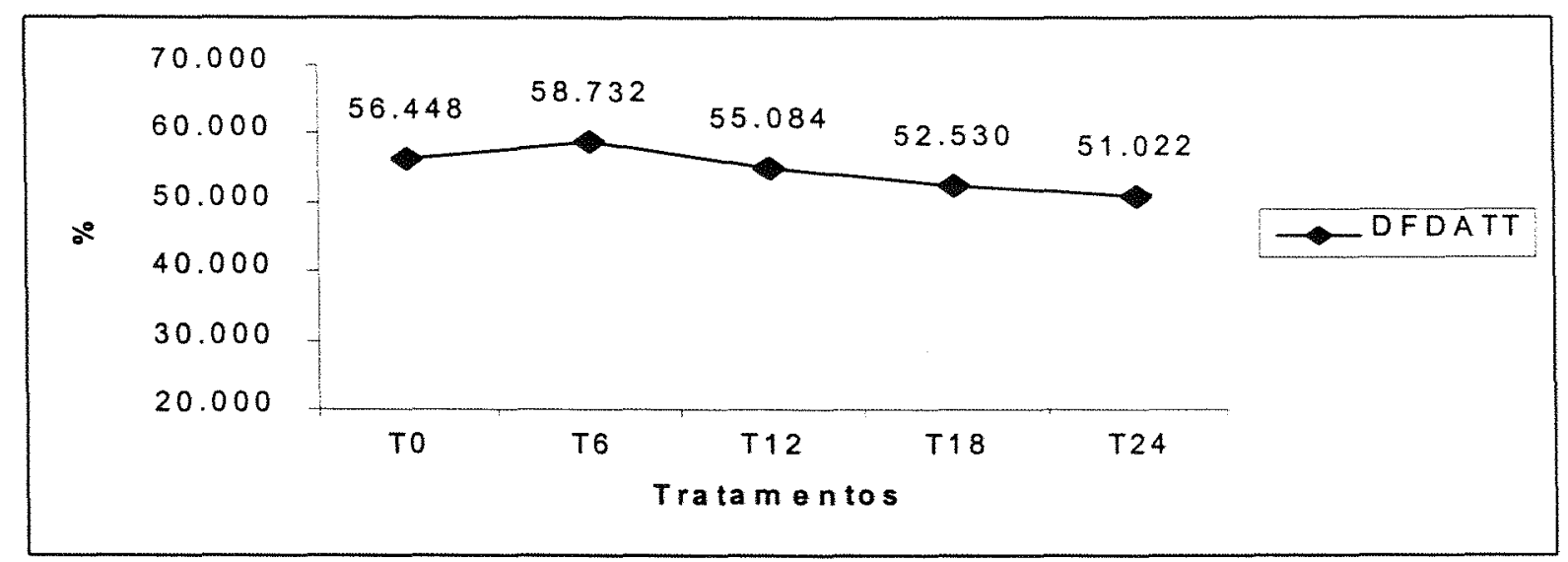

Figura 6. Efeito de níveis de caroço de algodão na digestibilidade aparente de FDA

O coeficiente de digestibilidade aparente do trato total da FDA diminuiu linearmente com o aumento de CA à dieta (Tabela 6, Figura 6). Esse resultado foi observado por Oliveira Junior (2000) quando acrescentou soja grão na dieta de cabras em lactação. Wu et al. (1994), quando comparou fontes e quantidades de suplementação com gordura para vacas em lactação, não observaram diferenças na digestibilidade aparente de FDA. Schauff \& Clark (1992) utilizando gordura protegida $(0,2$ e $5 \%)$ na dieta de vacas em lactação, não observaram alteração na digestibilidade aparente da FDA. Palmiquist \& Corand (1980) também não verificaram diferença na digestibilidade aparente da FDA com suplementação de gordura em dietas para vacas em lactação. 


\subsubsection{Proteína bruta}

O consumo médio e a digestibilidade aparente da proteína bruta no trato digestivo total, estão demonstrados na Tabela 7.

Tabela 7. Efeito da adição de caroço de algodão no consumo e digestibilidade da proteina bruta.

\begin{tabular}{|c|c|c|c|c|c|c|c|c|}
\hline \multirow[b]{2}{*}{ Itens } & \multicolumn{5}{|c|}{ Tratamentos } & \multicolumn{3}{|c|}{ Efeito } \\
\hline & TO & T6 & $\mathrm{T} 12$ & T18 & T24 & EPM & Linear & Quad. \\
\hline $\mathrm{CPB}, \mathrm{kg} / \mathrm{d}$ & 2,79 & 2,80 & 2,70 & 2,49 & 2,32 & 0,13 & 0,01 & 0,344 \\
\hline DPBTT, kg/d & 2,08 & 2,15 & 1,91 & 1,86 & 1,76 & 0,12 & 0,03 & 0,75 \\
\hline DPBTT, \% & 76,12 & 78,60 & 73,67 & 76,36 & 76,90 & 1,53 & 0,89 & 0,52 \\
\hline
\end{tabular}

O consumo de proteina bruta $(\mathrm{kg} / \mathrm{d}$; Tabela 7 ) diminuiu linearmente $(P<0,05)$, com a adição de caroço de algodão na dieta. Essa diminuição é decorrente a tendência linear de decréscimo no consumo de MS (Tabela 4), e a ocorrência não esperada de concentrados com diferentes teores de proteina bruta. Por esse motivos tivemos uma redução linear da digestibilidade aparente de proteína bruta em $\mathrm{kg} / \mathrm{d}$ com a suplementação de caroço de algodão. A digestibilidade aparente da proteína bruta em porcentagem não foi alterada com adição de caroço de algodão na dieta. O mesmo resultado foi observado na 
digestibilidade aparente de proteína em porcentagem com a adição de gordura à dieta de vacas em lactação (Palmiquist \& Corand, 1980; Bernard, 1990; Wu et al., 1994; Rabelo, 1995)

\subsubsection{Extrato etéreo e energia bruta}

O consumo médio e digestibilidade aparente do extrato etério e energia bruta no trato digestivo total, estão apresentados na Tabela 8.

Tabela 8. Efeito da adição de grão de soja no consumo e digestibilidade aparente do extrato etéreo $(E E)$ e energia bruta $(E B)$ no trato digestivo total.

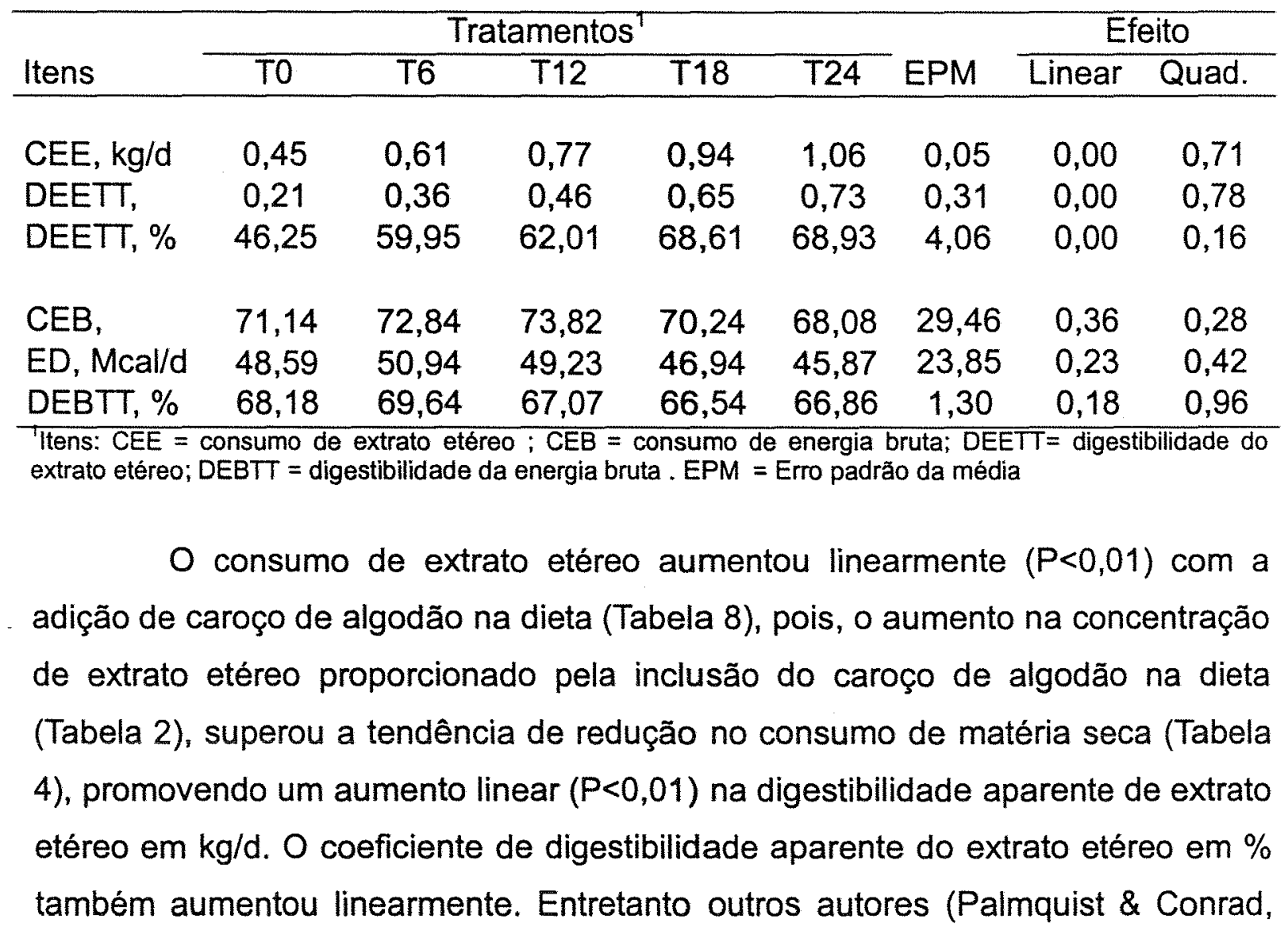


1980; Wu et al., 1994; Rabelo, 1995; Pereira et al., 1998) não demostraram alterações no coeficiente de digestibilidade aparente do extrato etéreo quando foram adicionadas outras fontes de gordura a dieta.

O consumo de energia bruta (Mcal/dia) não aumentou com a adição de caroço de algodão à dieta, pois apesar da densidade energética das dietas ter aumentado, houve redução do consumo de MS. Alguns experimentos publicados não verificaram redução na digestibilidade aparente da energia bruta quando suplementaram dietas com gordura (Palmquist \& Corand, 1978; Palmquist \& Conrad, 1980; Jenkins \& Jenny, 1989). Contudo, vários trabalhos publicados não determinam a digestibilidade da energia bruta.

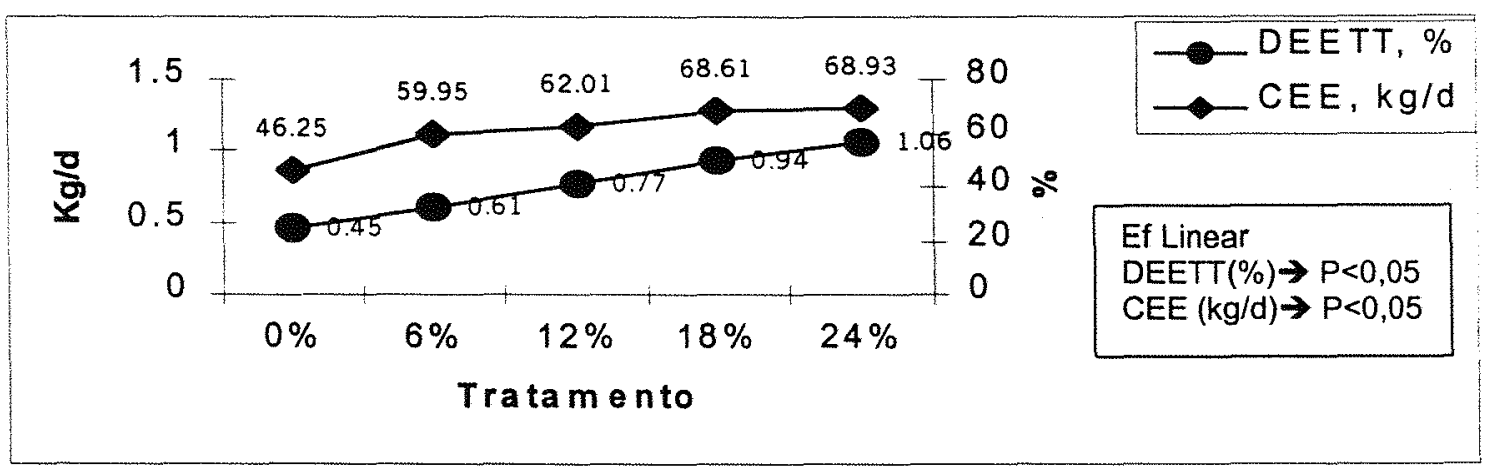

Figura 7 . Efeito de níveis de caroço de algodão na digestibilidade aparente de extrato etéreo e consumo de extrato etéreo. 


\subsection{Parâmetros ruminais}

\subsection{1 $\mathrm{pH}$}

O efeito da adição de caroço de algodão sobre $\circ \mathrm{pH}$ ruminal está apresentado na Tabela 9.

Tabela 9. Efeito da adição de caroço de algodão sobre o pH ruminal.

\begin{tabular}{|c|c|c|c|c|c|c|}
\hline \multirow[b]{2}{*}{ Tempos $^{2}$ (horas) } & \multicolumn{5}{|c|}{ Tratamentos } & \multirow[b]{2}{*}{ Subparcelas ${ }^{3}$} \\
\hline & TO & T6 & $\mathrm{T} 12$ & T18 & T24 & \\
\hline 0 & 6,09 & 6,27 & 6,21 & 6,33 & 6,21 & 6,22 \\
\hline 2 & 6,16 & 6,13 & 6,13 & 6,22 & 6,16 & 6,16 \\
\hline 4 & 5,98 & 6,03 & 5,94 & 6,03 & 5,95 & 5,99 \\
\hline 6 & 5,98 & 5,96 & 5,95 & 5,98 & 5,96 & 5,97 \\
\hline 8 & 6,07 & 6,04 & 5,97 & 6,14 & 6,12 & 6,07 \\
\hline 10 & 6,12 & 6,03 & 5,77 & 6,14 & 6,23 & 6,06 \\
\hline Parcelas ${ }^{4}$ & 6,07 & 6,08 & 6,00 & 6,14 & 6,11 & \\
\hline
\end{tabular}

Não houve diferença $(P>0,05)$ no $\mathrm{pH}$ entre os valores médios diários de cada tratamento (parcelas), ao longo do dia (subparcelas) e nem na interação tratamento $x$ tempo. Esse resultado também foi encontrado por Pires et al. (1997), Horner et al. (1988a) e Mohamed et al. (1988) quando acrescentaram caroço de algodão ou outra fonte de gordura na dieta de vacas em lactação. Entretanto, Horner et al. (1988b) demostraram que a adição de caroço de algodão provocou uma aumento de $\mathrm{pH}$. Esse efeito pode ser devido 
ao linter do caroço de algodão, ou pela redução de propionato e concentração AGVs total.

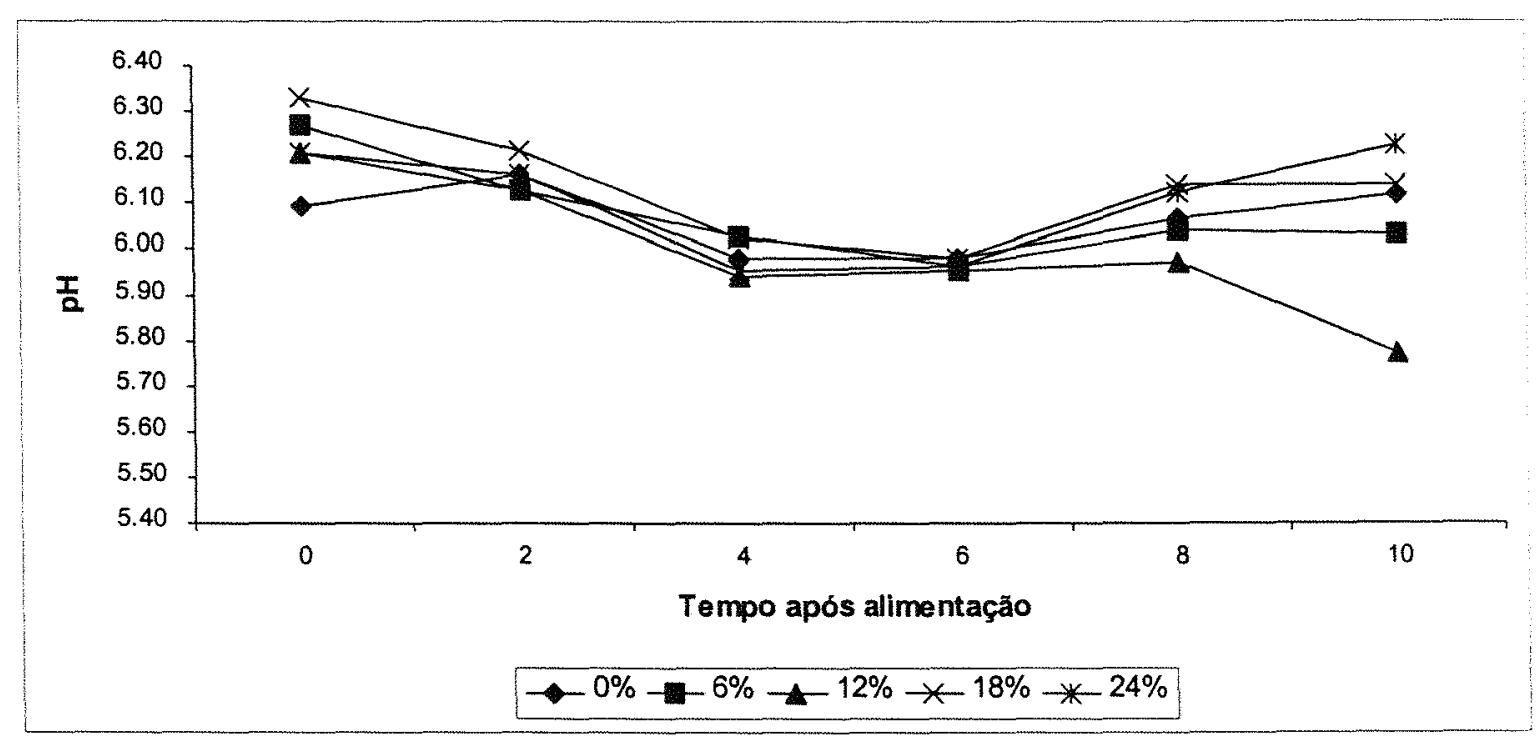

Figura 8. Variação diurna do $\mathrm{pH}$ ruminal em relação à porcentagem de inclusão de caroço de algodão na dieta.

\subsubsection{Concentração de ácidos graxos voláteis (AGV)}

\subsubsection{1 Ácidos graxos voláteis total.}

O efeito da adição de CA na concentração AGVs totais está apresentado na Tabela 10. A Figura 5 ilustra o comportamento da concentração de AGV no fluido ruminal. 
Tabela 10. Efeito da adição de caroço de algodão sobre a concentração de AGVs totais no fluido ruminal (mM).

\begin{tabular}{lcccccc}
\hline & \multicolumn{5}{c}{ Tratamentos } & \\
\cline { 2 - 6 } Tempos $^{2}$ (horas) & T0 & T6 & T12 & T18 & T24 & Subparcelas \\
\hline 0 & 97,83 & 98,91 & 104,19 & 99,20 & 98,06 & 99,64 \\
2 & 104,83 & 104,41 & 110,55 & 111,08 & 96,48 & 105,47 \\
4 & 96,27 & 107,46 & 109,60 & 101,70 & 101,65 & 103,33 \\
6 & 105,83 & 105,93 & 102,75 & 98,60 & 106,78 & 103,97 \\
8 & 97,58 & 102,29 & 103,22 & 93,23 & 100,44 & 99,35 \\
10 & 101,20 & 100,28 & 101,76 & 100,58 & 98,88 & 100,54 \\
Parcelas $^{4}$ & 100,59 & 103,21 & 105,34 & 100,73 & 100,38 & \\
\hline
\end{tabular}

Porcentagem de adição de caroço de algodão, ${ }^{2}$ Tempo após o fornecimento da ração, ${ }^{3}$ Média das subparcelas (tempo). ${ }^{4} \mathrm{P}>0,68$

Não houve diferença $(P>0,05)$ na concentração de $A G V$ s totais entre os valores médios de cada tratamento (parcelas) nem na interação tratamento $x$ tempo. Esse mesmo resultado foi encontrado por Keele et al. (1989), Pena et al. (1986), Horner et al. (1988a), Pires et al. (1997) quando adicionaram caroço de algodão ou outra fonte de gordura à dieta. Entretanto, Horner et al. (1988b) trabalhando com digestibilidade "in vitro", encontrou um diminuição de aproximadamente $7 \%$ com o aumento de caroço de algodão de $0 \%$ para $30 \%$ na dieta. 


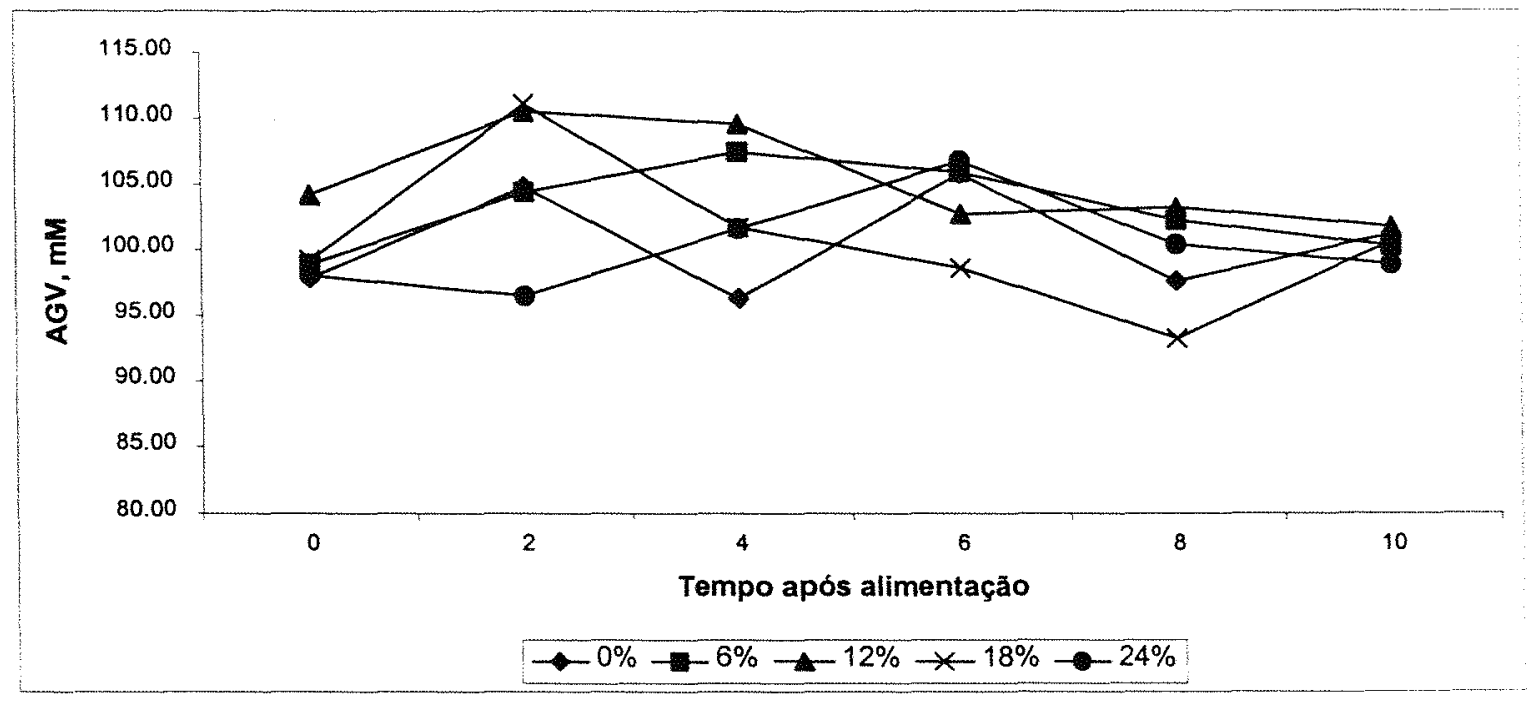

Figura 9. Variação diurna da concentração de $A G V s$ totais no fluido ruminal em relação à adição de caroço de algodão à dieta.

\subsubsection{2 Ácido acético}

O efeito da adição de caroço de algodão na concentração de acetato está apresentada na Tabela 11. A Figura 10 ilustra o comportamento da concentração de acetato no fluido ruminal.

Foi encontrado um efeito quadrático na concentração de ácido acético (C2) com o acréscimo de caroço de algodão à dieta (Figura 11). O aumento da proporção de ác. acético foi encontrada em outros trabalhos com a adição de caroço de algodão ou outra fonte de gordura a dieta (Horner et al., 1988b; Horner et al., 1988a; Pires et al., 1997). Essa resposta foi explicada pelos autores pelo aumento de linter proveniente do caroço de algodão à dieta, esse por sua vez é rico em fibra de alta degradabilidade ruminal. Entretanto Keele et 
al. (1989) e Mohamed et al. (1988) não encontraram variação na proporção de ác acético quando adicionaram uma fonte de gordura a dieta.

Tabela 11. Efeito da adição de caroço de algodão sobre a concentração de acetato no fluido ruminal $(\mathrm{mM})$

\begin{tabular}{lcccccc}
\hline & \multicolumn{5}{c}{ Tratamentos } & \\
\cline { 2 - 6 } Tempos $^{2}$ (horas) & T0 & T6 & T12 & T18 & T24 & Subparcelas $^{3}$ \\
\hline 0 & 69,11 & 69,07 & 69,76 & 69,08 & 68,72 & 69,15 \\
2 & 66,79 & 70,01 & 69,10 & 69,28 & 68,88 & 68,81 \\
4 & 68,76 & 69,10 & 69,34 & 68,12 & 68,11 & 68,69 \\
6 & 67,22 & 69,52 & 68,98 & 68,15 & 69,06 & 68,58 \\
8 & 68,68 & 69,19 & 69,62 & 68,70 & 68,41 & 68,92 \\
10 & 67,71 & 69,65 & 69,35 & 68,96 & 69,24 & 68,98 \\
Parcelas $^{4}$ & 68,05 & 69,42 & 69,36 & 68,72 & 68,74 & \\
\hline
\end{tabular}

Porcentagem de adição de caroço de algodão ${ }^{2}$ Tempo após o fornecimento da ração.

${ }^{3}$ Média das subparcelas (tempo). ${ }^{4}$ Efeito quadrático $\rightarrow P<0,02$

Os resultado quadráticos ( $P<0,05$; figura 11 ) encontrados foram devido a atuação de dois fatores. Até a concentração de $12 \%$ de caroço de algodão à dieta houve uma maior quantidade de fibra disponível para a fermentação ruminal, proporcionando com isso um aumento na produção de ác. acético. Entretanto, esse aumento de caroço de algodão, também aumentou a quantidade de gordura da dieta, e mesmo não encontrando uma diminuição da digestibilidade do FDN, houve um prejuizo na produção de ácido acético a partir de $12 \%$ de caroço de algodão. 


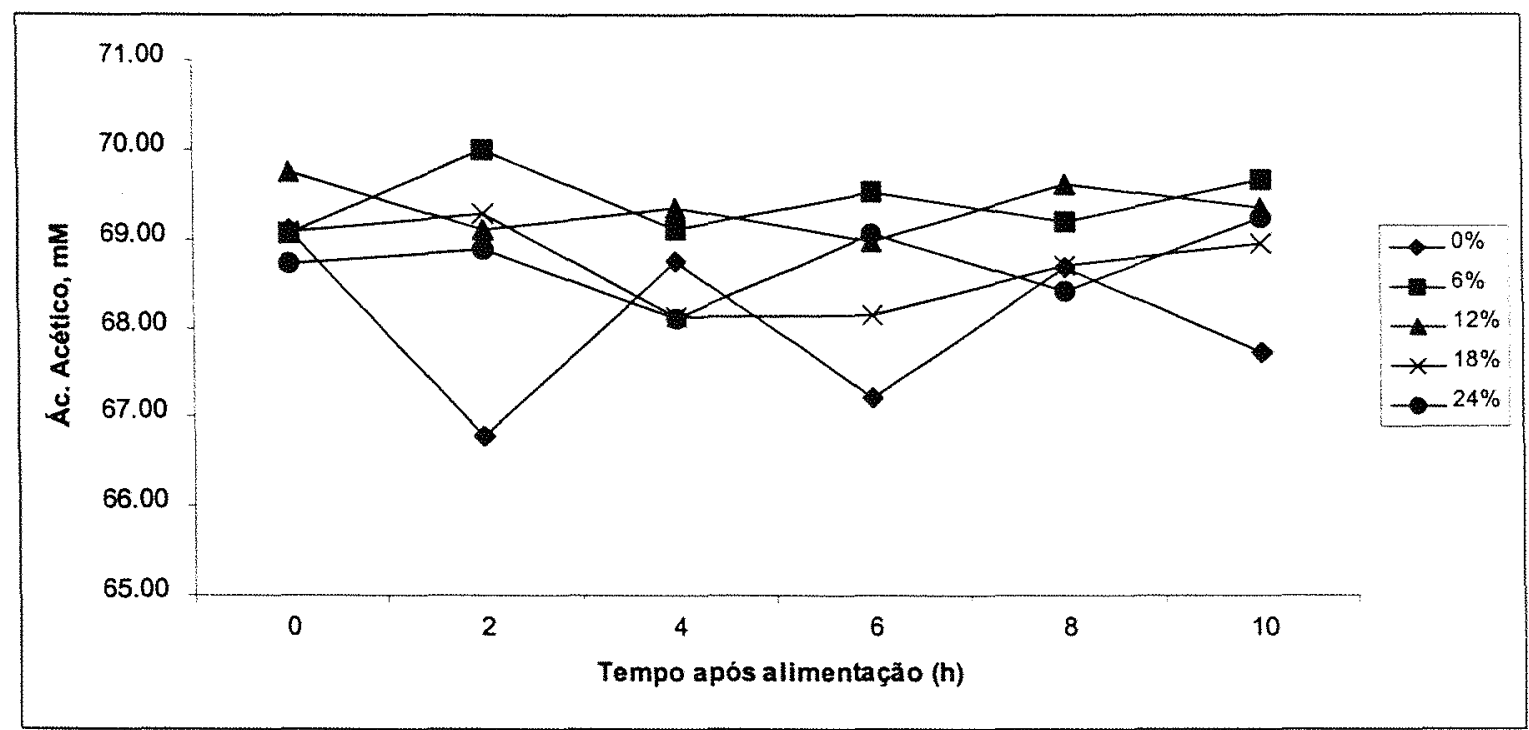

Figura 10. Variação diurna da concentração de ácido acético no fluido ruminal em relação a adição de caroço de algodão à dieta.

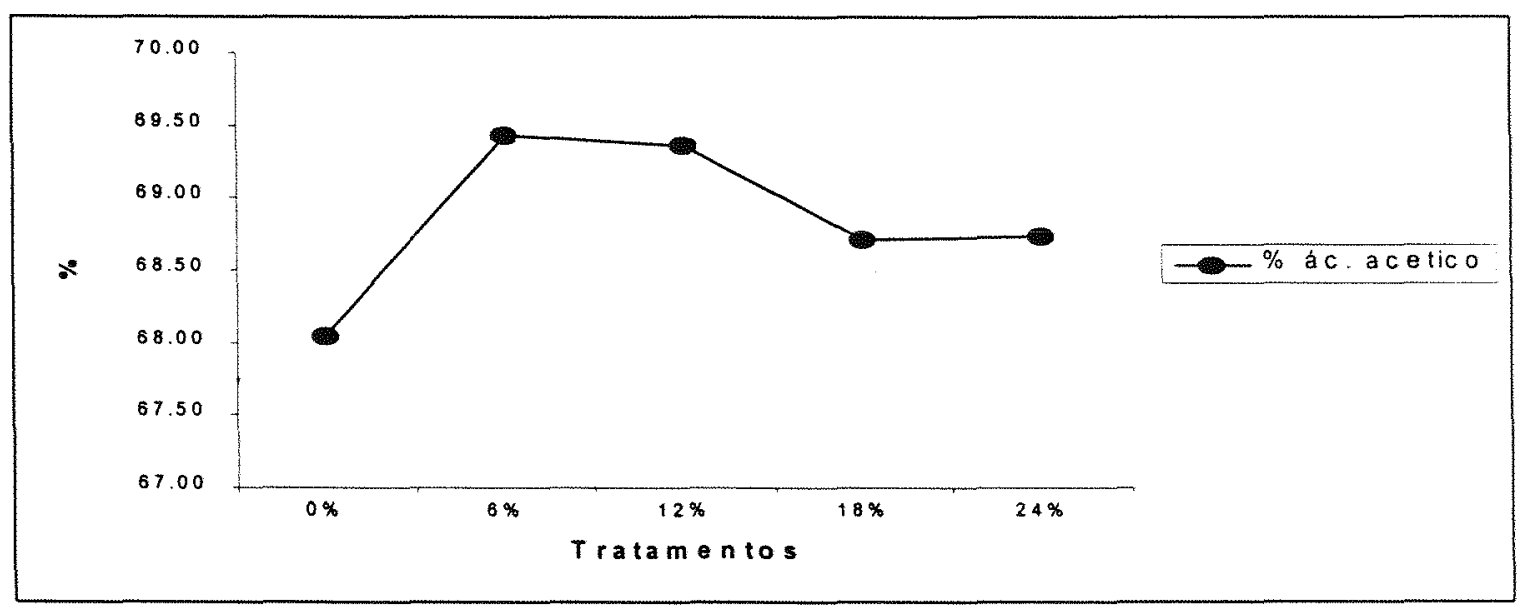

Figura 11. Efeito da adição de caroço de algodão na proporção de ácido acético. 


\subsubsection{3 Ácido propiônico}

Tabela 12. Efeito da adição de caroço de algodão sobre a concentração de ácido propiônico no fluido ruminal (mM)

\begin{tabular}{ccccccc}
\hline & \multicolumn{5}{c}{ Tratamentos $^{1}$} \\
\cline { 2 - 6 } Tempos $^{2}$ (horas) & T0 & T6 & T12 & T18 & T24 & Subparcelas \\
\hline 0 & 21,31 & 21,97 & 20,73 & 22,96 & 23,61 & 22,12 \\
2 & 23,75 & 21,34 & 21,49 & 22,77 & 23,23 & 22,52 \\
4 & 21,98 & 22,03 & 21,17 & 24,04 & 24,28 & 22,70 \\
6 & 23,28 & 21,90 & 21,44 & 23,84 & 23,14 & 22,72 \\
8 & 21,79 & 21,54 & 21,16 & 23,36 & 23,94 & 22,36 \\
10 & 22,83 & 20,75 & 21,28 & 22,79 & 23,17 & 22,17 \\
Parcelas $^{4}$ & 22,49 & 21,59 & 21,21 & 23,29 & 23,56 & \\
\hline
\end{tabular}

Porcentagem de adição de caroço de algodão ${ }^{2}$ Tempo após o for
${ }^{3}$ Média das subparcelas (tempo). ${ }^{4}$ Efeito Quadrático $\rightarrow P=0,060$.

A proporção de ácido propiônico em valores médios ao longo do dia e a interação tratamento $x$ tempo não foram afetadas $(P>0,05)$ com a adição de caroço de algodão à dieta (Tabela 12). Entretanto, houve um efeito quadrático $(P<0,05)$ na proporção média de ácido propiônico entre os tratamentos (Figura 13). Pires et al. (1997) não encontraram diferença na concentração de ácido propiônico quando adicionaram caroço de algodão à dieta. Já Horner et al. (1988a) observaram uma diminuição de propionato em dietas com $15 \%$ de caroço de algodão. Entretanto Mohamed et al. (1988) e Keele et al. (1989) encontraram um acréscimo na proporção de ácido propiônico quando adicionaram uma fonte de gordura na dieta.

O efeito quadrático ( $P<0,05 ;$ Figura 13) encontrado entre os tratamentos com a adição de caroço de algodão na dieta seguiu o comportamento observado por Horner et al. (1988), que observaram a diminuição de carboidratos degradáveis no rúmen devido a substituição pela 
gordura do caroço de algodão, diminuindo assim a proporção de ácido propiônico. Esse efeito foi observado até o nível de $12 \%$ de caroço de algodão da MS da dieta, com uma concentração de $4,53 \%$ de extrato etéreo na MS. Entretanto, a partir desta concentração de caroço de algodão observou-se um aumento na proporção de ácido propiônico. Essa característica pode ter sido por uma redução do número de protozoários no rúmen . O aumento da ingestão de ácidos graxos reduz o número de protozoários no rúmen (Tamminga et al., 1983; Pena et al., 1986).

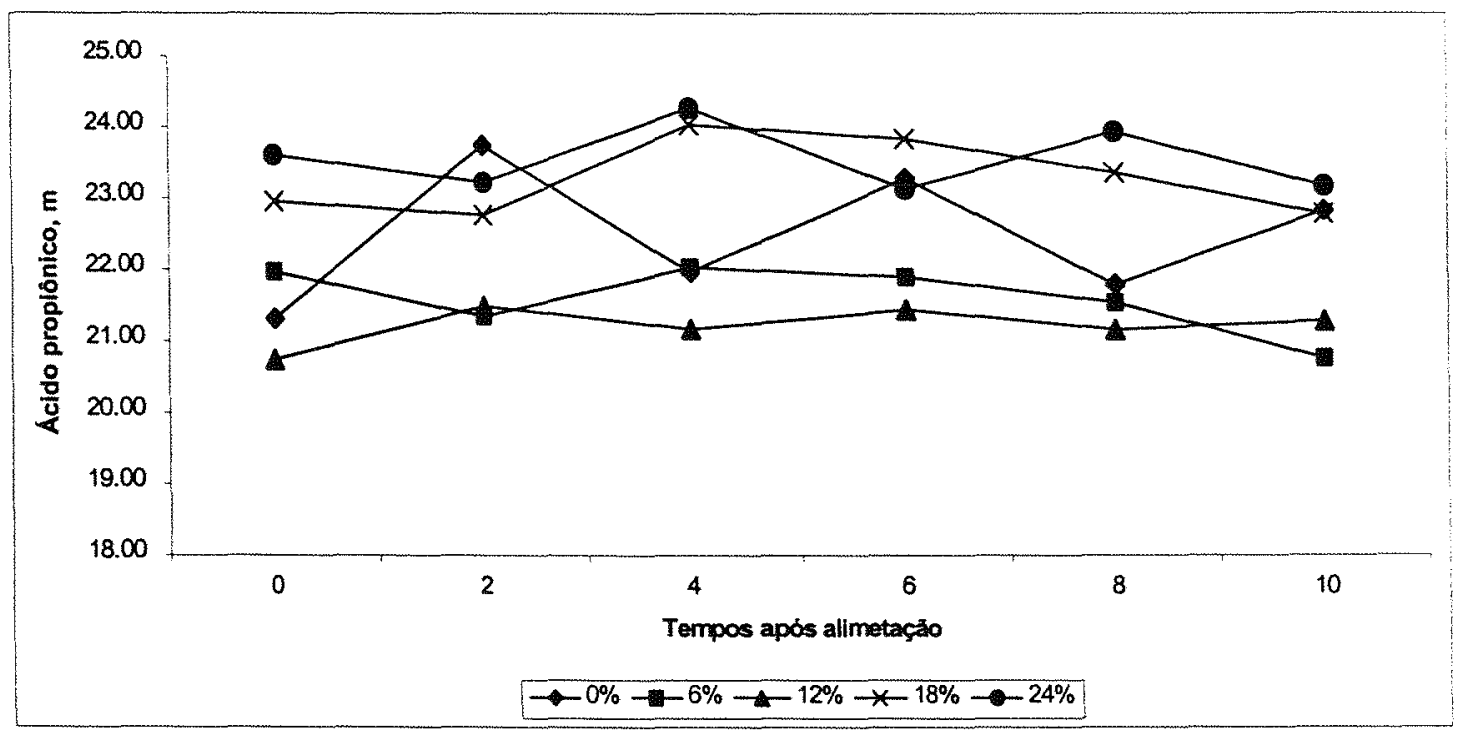

Figura 12. Variação diurna da concentração de ácido propiônico no fluido ruminal em relação a adição de caroço de algodão. 


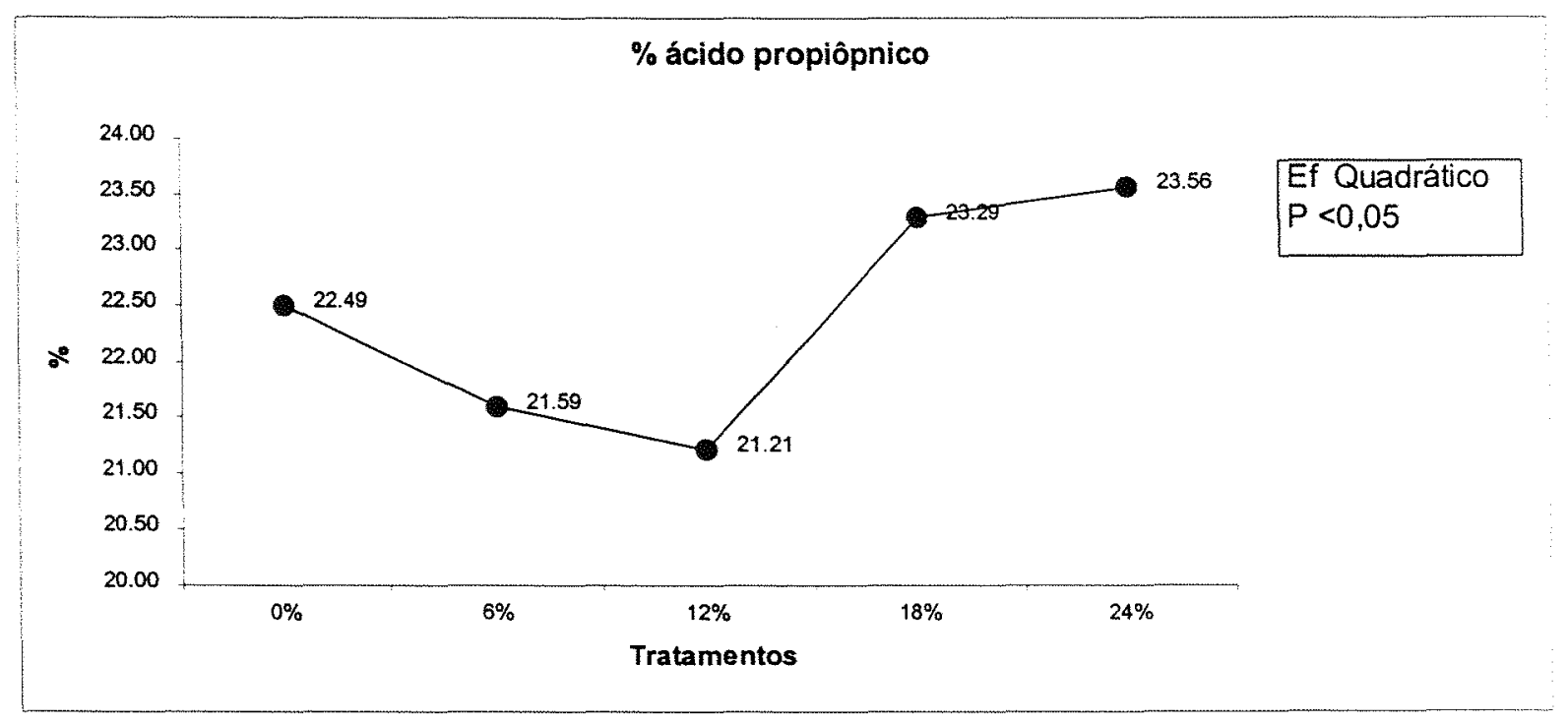

Figura 13. Efeito da adição de caroço de algodão na proporção de ácido propiônico 


\subsubsection{4 Ácido butírico}

O efeito da adição de caroço de algodão na concentração de ácido butírico está representado na Tabela 13.

Tabela 13. Efeito da adição de caroço de algodão sobre a concentração de ácido butírico no fluido ruminal (mM).

\begin{tabular}{lcccccc}
\hline & \multicolumn{5}{c}{ Tratamentos $^{1}$} & \\
\cline { 2 - 6 } Tempos $^{2}$ (horas) & T0 & T6 & T12 & T18 & T24 & Subparcelas \\
\hline 0 & 9,58 & 8,96 & 9,51 & 7,96 & 7,67 & 8,74 \\
2 & 9,46 & 8,66 & 9,41 & 7,95 & 7,89 & 8,67 \\
4 & 9,27 & 8,86 & 9,49 & 7,84 & 7,61 & 8,62 \\
6 & 9,50 & 8,58 & 9,59 & 8,01 & 7,80 & 8,70 \\
8 & 9,52 & 9,27 & 9,22 & 7,94 & 7,65 & 8,72 \\
10 & 9,46 & 9,59 & 9,37 & 8,26 & 7,59 & 8,85 \\
Parcelas $^{4}$ & 9,46 & 8,99 & 9,43 & 7,99 & 7,70 & \\
\hline
\end{tabular}

Porcentagem de caroço de algodão nas dietas ${ }^{2}$ Tempo após o fornecimento da ração.
${ }_{3}^{3}$ Média das subparcelas (tempo). ${ }^{4}$ Efeito Linear $\rightarrow P<0,01$

Não foi encontrado diferença estatística $(P>0,05)$ na concentração de butirato entre os valores médios ao longo do dia nem na iteração tratamento $x$ tempo. Entretanto, houve diferença $(P<0,05)$ dos valores médios diários de cada tratamento. Pires et al. (1997) encontraram valores similares para concentração de ác. butírico quando acrescentaram caroço de algodão à dieta.

A proporção de ácido butírico teve uma diminuição $(P<0,05)$ linear com o aumento de caroço de algodão na dieta. Essa resposta foi encontrada por Mohamed et al. (1988), Keele et al. (1986) e Horner (1988b), e é devido a um aumento do consumo de ácidos graxos de cadeia longa, pois esses causam uma redução do número de protozoários. 


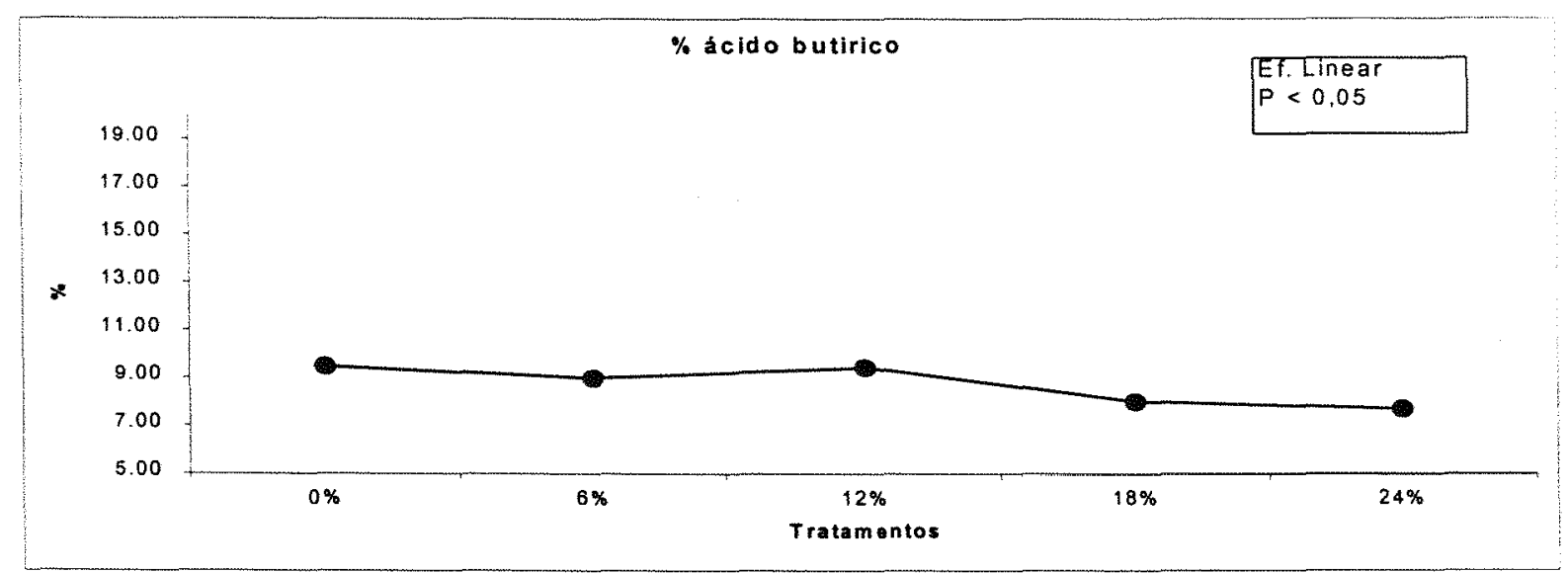

Figura 14. Efeito da adição de caroço de algodão na proporção de ácido butírico.

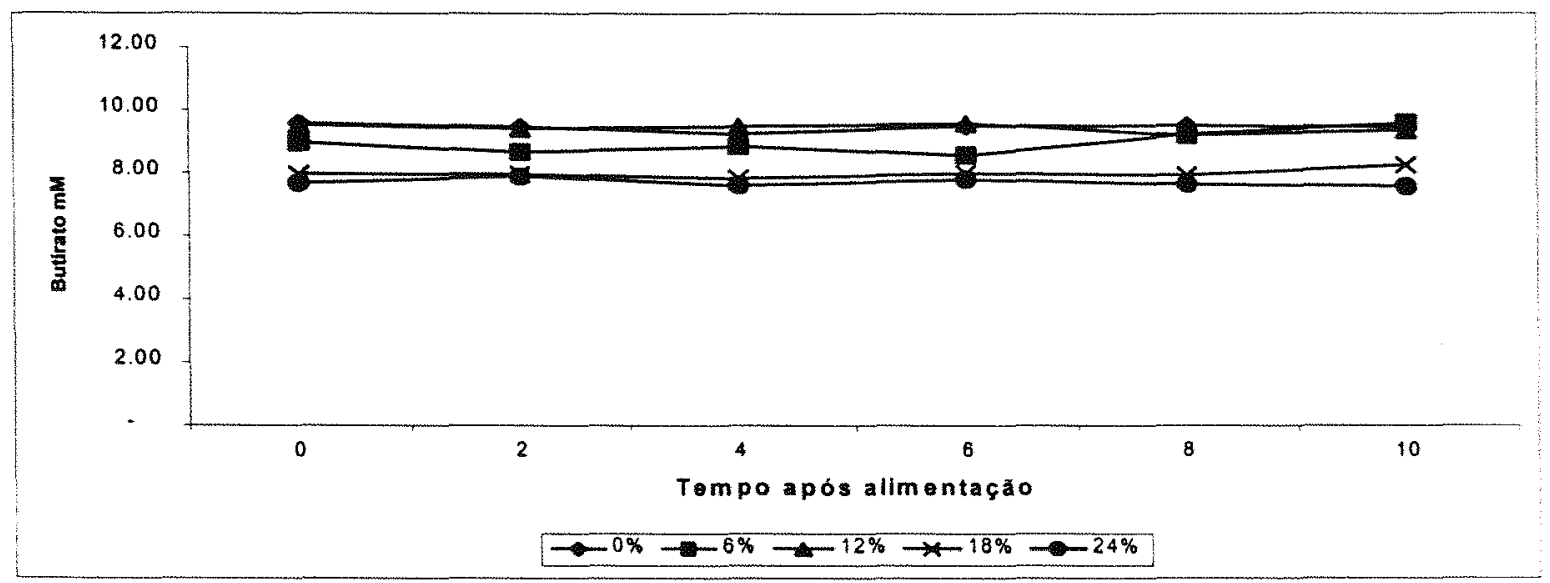

Figura 15. Variação diurna da concentração de ácido butírico no fluido ruminal em relação a adição de caroço de algodão. 


\subsubsection{Relação acético/propiônico}

O efeito da adição de caroço de algodão na relação acético/propiônico está apresentada na Tabela 14. A Figura 17 ilustra o comportamento da relação acetato/propionato no fluido ruminal.

Tabela 14. Efeito da adição de caroço de algodão sobre a relação acético/propiônico no fluido ruminal

\begin{tabular}{ccccccc}
\hline & \multicolumn{5}{c}{ Tratamentos $^{1}$} \\
\cline { 2 - 5 } Tempos $^{2}$ (horas) & T0 & T6 & T12 & T18 & T24 & Subparcelas ${ }^{3}$ \\
\hline 0 & 3,31 & 3,24 & 3,44 & 3,05 & 2,91 & 3,19 \\
2 & 2,94 & 3,33 & 3,26 & 3,10 & 3,00 & 3,12 \\
4 & 3,21 & 3,24 & 3,29 & 2,88 & 2,82 & 3,09 \\
6 & 3,02 & 3,26 & 3,23 & 2,92 & 3,01 & 3,09 \\
8 & 3,25 & 3,23 & 3,34 & 2,99 & 2,87 & 3,14 \\
10 & 3,13 & 3,38 & 3,27 & 3,10 & 3,01 & 3,18 \\
Parcelas $^{4}$ & 3,14 & 3,28 & 3,31 & 3,01 & 2,94 & \\
\hline
\end{tabular}

\footnotetext{
${ }^{3}$ Média das subparcelas (tempo). ${ }^{4} \mathrm{P}<0,01$
}

Não houve diferença estatística $(P>0,05)$ na relação acético/propiônico (Tabela 14) entre os valores de interação tratamento $x$ tempo, e nem diferença ao longo do dia. Houve uma diferença estatística quadrática entre os valores médios diários de cada tratamento.

Pires et al. (1997) não encontraram diferença na proporção acético/propiônico quando acrescentaram fontes de gordura na dieta de vacas leiteiras. Entretanto Mohamed et al., (1988) encontraram uma diminuição na proporção de acético/propiônico quando acrescentaram gordura a dieta. 
O efeito quadrático encontrado nesse trabalho pode ser explicado pelos aumentos de acético até o nível de $12 \%$ de CA e uma diminuição a partir desse ponto, juntamente com a diminuição de propionato até o mesmo ponto e o aumento a partir desse ponto em diante.

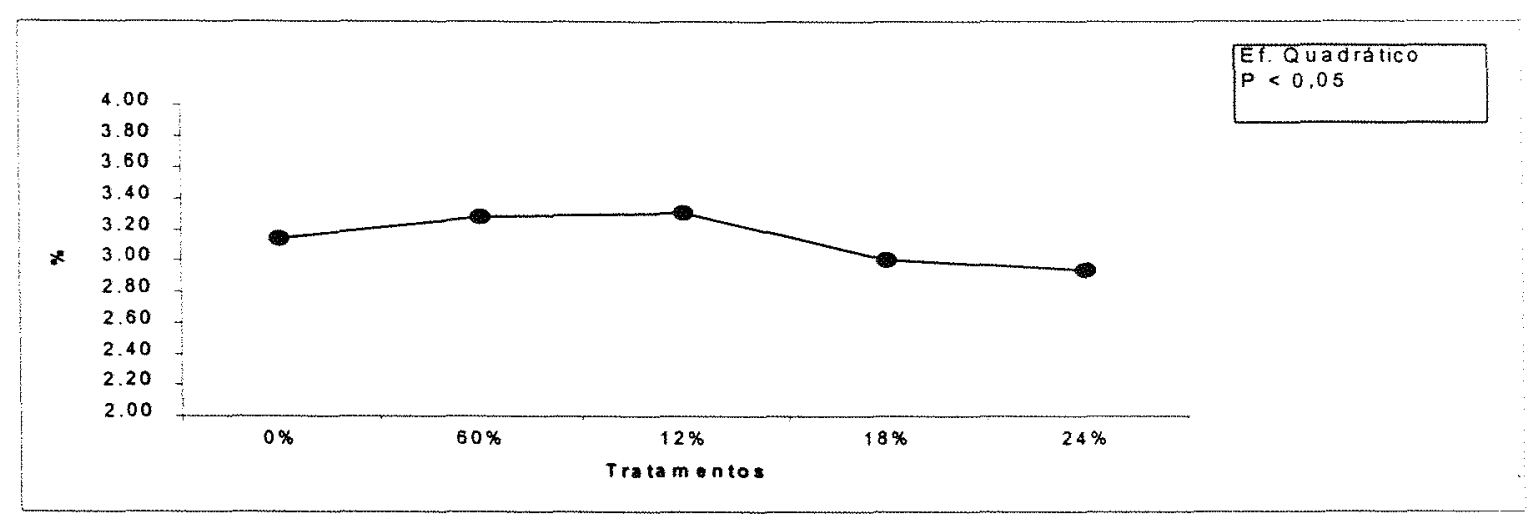

Figura 16. Efeito da adição de caroço de algodão na relação acético/propiônico.

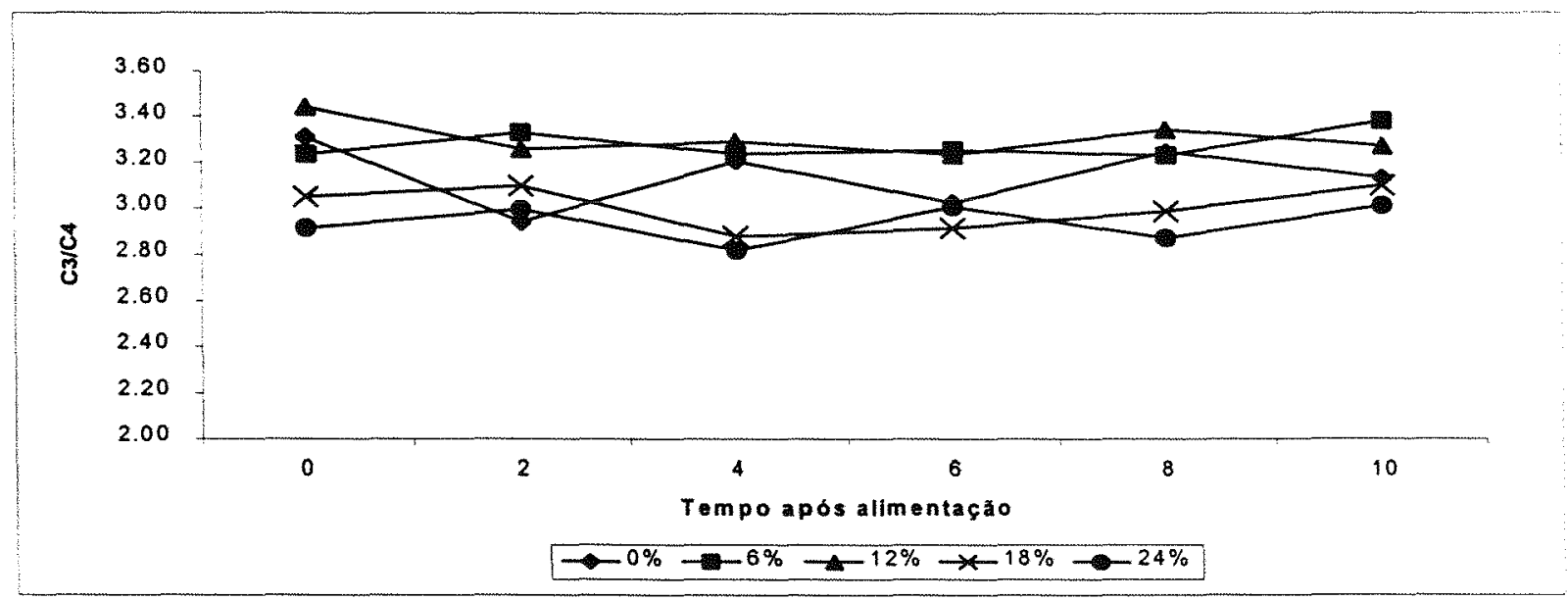

Figura 17 Variação diurna da concentração de ácido propiônico no fluido ruminal em relação a adição de caroço de algodão. 


\subsection{Digestibilidade in situ}

Os efeitos da adição de caroço de algodão na digestibilidade da matéria seca estão representadas na Tabela 15.

Ao comparar os niveis de caroço de algodão na dieta não se encontrou efeito linear da fração rapidamente solúvel (a) $(P>0,05)$, já a fração insolúvel em água, mas potencialmente degradável $(b)$ teve uma tendência linear $(P=$ $0,05)$, essa tendência observada refletiu sua taxa de degradabilidade (c). Esses resultados diferem dos obtidos por Teixeira (1996), que afirma não ter encontrado diferença nas frações (b) e (c) devido a solubilidade do caroço de algodão na forma moída ser maior. Já com alta relação volumoso concentrado (60:40) desse experimento não foi observado alta solubilidade do caroço de algodão.

Com o aumento dos niveis de caroço de algodão na dieta, não se encontro efeito linear nem quadrático $(P>0,05)$ da degradabilidade efetiva da matéria seca da dieta nas taxas de passagem de 2,5 e $8 \% / \mathrm{h}$.

Não foi encontrado efeito na fração solúvel das dietas $(P>0,10)$, provavelmente pela indiferença encontrada nas frações rapidamente solúvel e insolúvel em água, mas potencialmente degradável.

Foi encontrado efeito linear significativo $(P<0,05)$ para degradabilidade do material insolúvel e para a degradabilidade potencial. Houve uma diminuição desses parâmetros a medida que se acrescentou caroço de algodão à dieta. Essa queda provavelmente foi devido a um aumento da lignina juntamente como o acréscimo do caroço de algodão. A lignina da dieta foi de 0,$58 ; 1,59$; 2,$61 ; 4,14$ e 5,52 para os níveis de $0,6,12,18$ e $24 \%$ de caroço de algodão da dieta respectivamente. 
Tabela 15 - Parâmetros da degradabilidade in situ, das dietas, segundo Fit Curve.

\begin{tabular}{|c|c|c|c|c|c|c|c|c|}
\hline \multirow[t]{2}{*}{$\left.\right|^{\mid t e n s}{ }^{1}$} & \multicolumn{5}{|c|}{ Tratamentos } & & \multicolumn{2}{|c|}{ Efeito } \\
\hline & T0 & T6 & $T 12$ & T18 & T24 & EPM $^{2}$ & Linear & Quad. \\
\hline a & 23,90 & 23,02 & 23,14 & 18,20 & 22,28 & 2,155 & 0,259 & 0,557 \\
\hline b & 0,54 & 61,54 & 59,54 & 53,92 & 51,18 & 3,855 & 0,051 & 0,456 \\
\hline c & 044 & 0,045 & 0,061 & 0,082 & 0,078 & 0,012 & 0,025 & 0,925 \\
\hline 0,0 & 64,06 & 64,12 & 65,98 & 60,22 & 62,62 & 1,974 & 0,298 & 0,697 \\
\hline 0,05 & 51,46 & 51,66 & 53,92 & 50,40 & 53,04 & 1,672 & 0,725 & 0,888 \\
\hline 0,08 & 45,06 & 44,48 & 47,40 & 44,70 & 47,20 & 1,360 & 0,316 & 0,917 \\
\hline FS & 18,96 & 14,98 & 22,42 & 21,32 & 19,66 & 1,482 & 0,124 & 0,495 \\
\hline DMI & 65,48 & 69,54 & 59,80 & 50,76 & 53,76 & 3,592 & 0,002 & 0,917 \\
\hline $\mathrm{DP}$ & 84,44 & 84,58 & 82,22 & 72,08 & 73,44 & 3,325 & 0,006 & 0,675 \\
\hline
\end{tabular}

${ }^{1}$ Itens: $a=$ fração rapidamente solúvel em água; $b=$ fração insolúvel em água,

mas potencialmente degradável; $c=$ taxa de degradação da fração $b ; F S=$ fração solúvel; DMI = degradabilidade do material insolúvel; DP = degradabilidade potencial.

${ }^{2}$ Erro Padrão da média. 


\section{CONCLUSÃO}

Com a adição de níveis crescentes de caroço de algodão na dieta de vacas em lactação contendo silagem de milho, conclui-se:

- Tendência na redução do consumo de M.S. e M.O.

- Diminuição na digestibilidade aparente da M.S. e M. O.

- A digestibilidade da PB, do FDN e EB não foram alteradas.

- Aumentou a digestibilidade aparente do extrato etéreo.

- Diminuiu a digestibilidade aparente do FDA.

- Os paramentos ruminais ( $\mathrm{pH}$ e AGVT) não diferiram entre os tratamentos.

- A produção de leite e de proteína do leite teve um efeito quadrático.

- A porcentagem de gordura do leite aumentou linearmente.

- A degradabilidade efetiva da M.S. nas taxas de passagem de 2; 5; e 8\%, assim como a fração rapidamente solúvel e insolúvel em água não sofreram alterações 


\section{REFERÊNCIAS BIBLIOGRÁFICAS}

AGRICULTURE RESEARCH COUNCIL - ARC. Energy and protein requiremente of ruminants. Walling: CAB International. 1993.

ADAMS, A. L. Efect of secondary forage type on production of dairy cows fed corn silage-based rations supplemented with whole cottonseed, tallow, and yeast M. S. thesis Sairy Science Depart., Univ. Florida, Gainesville. 1993.

ANDERSON,M.J., D.C. ADANMS, R. C. LAMB, e J.L. WALTERS. Feeding whole cottonseed to lactating dairy cows. J. Sairy Sci. 62: 1098. 1979

A. O. A. C. Official methods of analysis (13 ed.). Association of Official Agricultural Chemists, Washington, 1980.

ASTRUP, H.N.,L. VIK-MO,A. ERERN, e F. BAKKE. Feeding protected and unprotected oils to daiuy cows. J. Dairy Sci. 59: 426.1976.

BAUCHART, C.,F. LEGAU-CARMIER, M. COREAU. e V. GAILLARD. Lipid metabolism of liquid-associated and solid-adherent bacteria in rulmmen contentes of dairu cows offered lipid-supplemental diets. Bri. J. Nutri. 63: 563. 1990. 
BERNAD, J.K. Effects of raw or roasted whole soybeans on digestibility of dietary nutrients and milk production of lactating daity cows. J. Dairy Science, v.73, p.3231-3236,1990.

BITMAN, JH.; WOOD, D.L.; MILLER, R.H.; TYRRESLL, H.F.; REYNOLDS, C.K.; BAXTER, H.D. Comparison of milk and blood lipids in jersey and holstin cows fed total mixid rations with or without whole cottonseed. J. Dairy Sci., V.79, p79, p.1596-1602, 1996.

BOGGS, D.L., W.G. BERGEN, e D.R. HAWKINS.. Effects of tallow supplementation and protein withdrawal on ruminal fermentation, microbial synthesis and site of digestion. J. Animal. Sci. 64:907. 1987

BYERS, F.M. SCHELLING G.T. Lipids in ruminant nutrition. In: CHURCH D.C. (Ed.) The ruminant animal digestive physilogy and nutrition. New Jersey: A reston book, 1988. Cap 15, p. 298-312.

CHALUPA, W., B. VECCHIARELLI, A. E. ELSER, D. S. KRONFELD, e D. SKLAN. Ruminal fermentation in vivo as influenced by long-chain fatty acids. J. Dairy Science. 69:1293. 1986.

CHIK, A. B. Effect of dietary whole cottonseed on lactational performance and digestibility as related to roughage source, protein source, and calcium treatment. PhD Dissertation, Dairy Science Dept., Universidade Florida Gainesville. 1987.

CLARD, P.W. e L. E. ARMENTANO; Replacemente of alfalfa neutral detergent fiber with a combination fo nonforage fiber sources. J. DAIRY SCI. 80:675680. 1997. 
COPPOCK,C.E., J.K. Lanham, e J. I. Horner. A Review of nutritive value and utilization of whole cottonseed, cottonseed meal and associated by-products by dairy cattle. Animal Feed Sci. Technol. 18:98. 1987.

COPPOCK, C.E.; WILKS, D. L. Suplemental fat in high-energy rations for lactating cows: effects on intake, digestion, milk yield and composition. Journal Animal Science, v 69, p.3826-3837, 1991.

CZERKAWSKI, J.W.. Effect of linseed oil fattu acids and linseed oil on rumen fermentation in sheep. J. Dairy Sci. 81: 517. 1973.

DePETERS, E. J., S.J. TAYLOR, A. A. FRANKE, e A. AGUIRRE.. Effects of feeding whole cottonseed on composition of milk . J. Daitu Sci. 68:897. 1985

DEVENDRA, C. e D. LEWIS. The interaction between dietary lipids and fibre in the sheep. Animal Production. 19:67, 1974.

DRACKLEY, J. K. e J. P. ELLIOTT.. Milk composition, ruminal cjaracteristics, and nutrient utilization in dairy cows fed partiallu hydrogenated tallow. J. Dairy Sci. 77: 1386. 1993.

DRACKLEY, J. K. , D. E., GRUM, G. C. McCOY, e T. H. KLUSMEYR. Comparison of three methods for incorporation of liquid far into diets for lactating cows. J. Dairy Sci. 77:1386, 1994.

DUNKLEY, W. L., N. E. SMITH. e A.A. FRANKE., Effects of feeding protected tallow on co position of milk and milk fat. J. Dairy Sci. 60:1863. 1977. 
EASTRIDGE, M.L. e J.L.FIRKINS. Feedingt hydrogenated fatty accids and triglycerides to lactyating dairy cows. J. Dairy Sci. 74: 2610. 1991.

ERDMAN, R.A. Trans fatty acids and fat synthesis in milk. Southwest Nutrition \& Management conference. Phenix, Arizona, 1999.

ELLIOT. J.P., T.R. OVERTON, e j. K. DRACKELEY. Digestibility and effects of three forms of mostly saturated fatty acids. J. Dairy Sci. 77: 789. 1994.

ERWIN, E.S., W. STERNER, e G.J. MARCO.. Effect of type of olil and site of administration on the fate oj fatty acids in sheep. J. Am. Oil Chem. Soc. 40:344. 1963

FENTON, T. W. e FENTON. An improved procedure for determination of chromic oxide in fed and feces. Canadian Journal Animal Science, v. 59 , p. $631-34,1979$.

FERGUNSON, J. D., J. TORRALBA, P. L. SCHRNEIDER, B. BRCCHIARELLI, D. SKLAN, D.S. KRONFELD, E W. CHALUPA.. Response of lactating cows in commercial dairies to calcium salts of long chain fatty acids. J. Dairy Sci. 71 (Suppl. 1): 254 (Abstr.) 1988.

GERSON, T.,A. JOHN, e B.R. SINCLAIR. The effect oj dietary $N$ on in vitro liplysis and fatty acid hydrtogenation in rumen digesta from sheep fed diets high in starch. J. Agri. Sci. 101:97. 1983.

GOERING, H.K., T.R. WRENN, L.F. Edmondson, J.R. WEYANT, D.L. Wood, e J. BITMAN. Feeding polyunsatured vegetable oils to lactating cows. J. Dairy Sci. $60: 739.1977$ 
GRANT, R.J.; WEIDNER, S.J. Effect of fat from whole soybeans on performance of daity cows fed rations differing in fiber level and particle size Jornal of daity Science, v. 75, p. 2742-2741, 1992.

HAWKINS, F.E.,; CUMMINS, K.A.; SILVEIRIO, M.; JULEK, J.J. Physuikigucal effects of whole cottonseed in diet of dairy cows. Jounal of Dairy Science, v.68, p 2608-2615,1995.

HILD, F.J.R., R.B. JACKSON, e M.J. WEIDEMANN. Transport and metabolism of fatty acids by isolated rumen epithelium. Biochen J. 98:394. 1966.

HARFOOT, C.G.. Lipid metabolism in the rumen. In: Lipid metabolism in ruminant animals. W. W. Christie, ed. Pergamon Press, Oxford, NY., pp. 21-55. 1981

HENDERSON, C. The effects of fatty acids on pure cultures of rumen bacteria. J. Agri. Sci. 81: 107. 1973.

HOFFMAN, P.C., R.R GRUMMER, R. D.SHAVER, G. A. BRODERICK, E T.R. DRENDEL.. Feeding supplemental fat and undegraded intake protein to early lactation dairy cows. J. Dairy Sci. 74: 3468. 1991

HORNER, J.L., C.E. COPPOK, J.R. MOYA, J.M. LABORE, \& J.K. LANHAM. Effects of niacin and whole cottonseed on ruminal fermentation, protein degradability, and nutrient digestibility. J. Dairy Sci. 71: 1239. 1988a.

HORNER, J.L.; L.M. WINDLE, C.E. COPPOCK, J.M. LABORE; JLKL LANHAM; E D.H. NAVE. Effects of whole cottonseed, niacin, and niacinamide on In Vitro rumen fermentation and on lactating holsteins cows. J. Dairy Sci 71, n $121988 b$ 
JENKINS, T. C. e B. F. JENNY. Effects of hidrogenated fat on feed intake, nutrient digestibility of dairy cows. J. Dairy Sci. 72:2316. 1989.

JENKINS,T.C. e N. FOTOUHI. Efects of lecithin and corn oil on site of digestion, ruminal fermentation and microbial protein synthesis in sheep. J. Anim. Sci. 68:460. 1990.

JENKINS, T.C. e V.F. JENNY. Nutrient digestion and lactation performance of dairy cows fed combinations of prilled fat and canola oil. J. Sairy Sci. 75: 796. 1992.

JERRED, M.J., D.J. CARROLL, D. K. COMBS, e R. R. GRUMMER. Effects of fat supplementation and immature alfalfa to concentrate ratio on lactation performance of cattle. J. Dairy Sci. 73:2842. 1990.

KAJIKAWA, H.,M. ODAI, M.SAITOH. e A. Abe.. Effects of whole cottonseed on ruminal properties and lactation performance of cows with different rumen fermentation patterns. Anim. Feed Sci. Technol. 34:203. 1991

KANAPP, D.M., R.R. GRUMMER, e M.R. DENTINE. The response fo lactating dairy cows to increasing levels of whole soybeans. J. Dairy Sci. 74:2463. 1991.

KEPLER, C.R., W.P. TUCKER, e S.B. TOVE. Biohidrogention of unsaturated fatty acids. J. Biol. Chem. 245:3612. 1970.

KEELE, J.W. R.E. ROFFLER e K.Z. BEYERS. Ruminal metabolism in nonlactating cows fed whole cottonseed or extruded soybeans. J. Anim. Sci. $67: 1612-1622,1989$. 
KLUSMEYER, T.H. e J.H. CLARK. Effects of dietary fat and protein on fatty acid flow to the dyuodenum and in mild produced by dairy cows J. Dairy Sci. 74:3055. 1991.

KRONFELD, D.S., S. DONOGHUE, J.M. NAULOR, H. JOHNSON, e C.A. BRADLEY. Metabolic effects of feeding protected tallow to dairy cows. J. Dairy Sci. 63:545. 1980.

LANHAM, J.K., C.E. COPPOCK, K.N. BROOKS, WILKS, e J.L. HORNER. Effects of whole cottonseed or niacin or both on casein synthesis by lactating holstein cows. J. Dairy Sci. 75:184-192. 1992.

LU, C.D. Implication of feeding isoenergetic diets containing animal fat on milk composition of alpine does during early lactation. Journal animal Science. V.7 (suplem.1) p. 305-305. 1988.

LEONARD, M. e E. BLOCK.. Effects of ration protein content and solubility on milk production fo primiparous Holstein heifers. J. Dairy Sci. 71:2709. 1988.

MACLEOD, G.K., Y.YU, e L.R. SCHAEFFFER. Feeding value of protected animal rallow for high yielding dairy cows. J. Dairy Sci. 60:726. 1977

MACLEOD, G.K.; WOOD, A.S.; YAO, T.Y. Influence of dietary fat on rumen fatty acids, plasma lipid and milk fat composition in the cows. Journal of Dairy Science, v.55, p.446-453, 1972.

MATTOS, W. e D.L. PALMQUIST. Increased polyunsaturated fatty acids yields in milk of cows fed protected fat. J. Dairy Sci. 57:1050-1054. 1974. 
MIELKE, C.D.; SCHINGOETHE, J. Heat-treated soybeans for lactating cows. Journal of Dairy Science, v.64 p,1579-1585, 1981.

MOHAMED, O.E., L.D. SATTER, R.R. GRUMMER, e F.R. EHLE. Influence of dietaru cottonseed and soubean om milk production and composition. J. Dairy Sci. 64:1579, 1988.

NATIONAL RESEARCH COUCIL-NRC. Nutrient requirements of dairy cattle. 6 th rev. ed. Natl Acad. Press . Whashington. 1989. 158p

Oliveira Junior R.C. Efeitos da niveis da grão de soja na digestibilidade de nutrientes e no desempenho da lactação de cabras leiteiras. Piracicaba, São Paulo, 2000, 67p. Dissertação (M.S.) ESALQ/ Universidade de São Paulo.

ORSKOV, E. R. e McDONALD., The estimation of protein degradability in the rumem from incubation measurements weighted according to rate of passage. J. Agric. Sci. (camb), 92:499p 1979.

PALMQUIST, D. L.; CONRAD, H. R. High levels of raw soybeans for dairy cows. J. Anim. Sci. v. 33:295. 1971.

PALMQUIST, D.L.. e H. R. CONRAND.. High fat rations for dairy cows. Effects on feed intake, milk and fat production, and plasma metabolites. J. Dairy Sci. 61:890. 1978.

PALMQUIST, D.L.. Feed ingredientes and management to maximize use of fat in dairy rations. Proc. California Anim. Nutr. Conf., 106. 1987. 
PALMQUIST, D. L. e H. R. CONRAND. High fat rations for dairy cows. Tallow and hydrolyzed blended fat at two intakes. J. Dairy Sci. 63: 391. 1980.

PALMQUIST, D.L. e E.A. MOSER. Dietary fat efeects on blood insulin glucose utilization, and milk protein content of lactating cows. J. Dairy Sci. 64:1664. 1981.

PALMQUIST, D.L.; CONARAD, H.R. Influence of source and amount of dietary fat on digestibility in lactating cows. J. Dairy Sci. 74:1354-1360, 1991.

PENA, F.; H. TAGARIL; e L.D. SATTER. The effect of heat treatment of whole cottonseed on site and extent of protein digestion in daity cows. J. Animal Sci. 62: 1423-1433. 1986.

PEREIRA, C.M.A. SILV, J.F.C.; VALADARES FILHO, S.C.; CAMPOS J.M.S.; CECON, P.R. Grãos de soja moida na ração de vacas em lactação. 2 produção e composição o leite. Rev. Bras. De Zootecnia. V.27, n.6, p. 1225-1233,1998.

PIRES V.A.; EASTRIDGE, M.L.; FERKINS, J. L. Roasted soybeans, blood meal, and tallow as sources of fat and ruminally yndegradable protein in the diets of lactating cows. J. Dairy Science. V79, p.1603-1610, 1996.

PIRES V.A.; EASTRIDGE, M.L.; FERKINS, J. L. e Y. C. LIN Effects of Heat treatment and physical processing of cottonseed on nutrient digestibility and production performance by lactating cows. J. Dairy Sci. 80:1685-1694. 1997. 
RABELO, T.G. Grão de soja moído na alimentação de vacas lactantes. Viçosa, Minas Gerais, 1995. 114p. Dissertação (M.S.) Universidade Federal de Viçosa.

REISER, R., e H. G. R. REDDY, The hydrogenation of dietary unsaturated fatty acids. J. Amer. Oil Chemists' Soc. , 33:155, 1956.

RUEGSEGGER, G.J. e L.H. SCHULTZ. Response of high producing dairy cows in early lactation to ghe feeding of heat-treted whole soybeans. J. Dairy Sci. 68:3272. 1985.

SAS Institute Inc. SAS/STAT User's Guide, ed. Cary, NC. 1988.

SCAUFF, D.J.; CLARK, J.H. Fffects of feeding diets containing calcium salts of long-chain fatty acids to lactating dairy cows. J. Dairy Sci. V:75, p29003002, 1992.

SIMAS J.M.C. Effect of sorghum grain processing and fat supplementation on performance and nutrient utilization in lactating dairy cows. PhD. thesis Departmente of animal sciences., Univ. Arizona. 1995.

SKAAR,T.C., R.R. GRUMMER, M.R. DENTINE, e R.H. SAUFFACHER. Seasonal effects of prepartum and postpartum fat and niacin feeding on lactation performance and lipid metagolism. J. Dairy Sci. 72:2028. 1989.

SMITH, N.E., W.L. DUNKLEY, e A. A. FRANKE. Effects of feeding protected tallow to dairy cows in early lactation. J. Dairy Sci . 61: 747. 1978. 
SMITH, N.E., L.S. COLLAR, D.L. BATH, e W.L. DUNKLEY. Digestibility and effects of whole cottonseed fed to lactating cows. J. Dairy Sci. 64:2209. 1981.

SMITH, W. A. , B. HARRIS, Jr., H. H. Van Horn, e C. J. Wilcox. Effects of forrage tyupe on production performance of dairy cows supplemented with whole cottonseed, tallow, and yeast. J. Dairy Sci. 73:3512 1993.

SUKHIJA, P.S. E D. L. PALMQUIST.1988. Rapid method for determination of total fatty acid content and composition fo feedstuffs and feces. J. Agric. Food Chem. 36: 1202

TAMMINGA, S.; A. M. van VUUREN, C.J. van der Koelen, H. M KHATTAB e L.G.M. Van GILS. Furter studies on the effect of fat supplementation of concentrates fedto lactating dairy cows. 3 Effect on rumen fermentation and siteof digestion of dietary components. Neth J. Agric. Sci. 31:249.1983

TEIXEIRA, J.C.; R.M. SANTOS; e A.I.F. OLIVEIRA, Degradabilidade ruminal da matéria seca, proteína bruta e fibra em detergente neutro de rações contendo caroço de algodão e grão de milho, em diferentes formas físicas, em vacas da raça holandesa. Rev Soc. Brasileira de Zootecnia. V.25 n. 4 1996.

TICE, E.M., M.L. EASTRIDGE, e J.L. FIRKINS.. Raw soybeans and roasted soybeans of different particle size. 1. Digestibility and utilization by lactating cows. J. Dairy Sci. 76:224. 1993

TICE, E. M., M.L. EASTRIDGE, e J.L. FIRKIINS.. Raw soybeans and roasted soybeans of different partcle sizes. 2 . Fatty acid utilization by lactating cows. J. Dairy Sci. 77:166. 1994 
VAN SOEST, P.J., J.B. ROBERTSON, e B.A. LEWIS.. Methods for dietary fiber, neutral detergent fiber, and nonstarch polysaccharides in relation to animal nutrition. J. Dairy Sci. 74:3583. 1991

VILLELA. S. D. J.; S. C. Velasques FILHO; J. F. C SILVA; M.I. LEÃO; P.R. CEON; J.C. PEREIRA. Caroço de algodão para vacas leiteiras 1. Consumo de nutrientes, produção e composição do leite. R Bras. Zootec., v.25, n.2, 1996.

VILLELA. S. D. J.; S. C. Velasques FILHO; J. F. C SILVA; P.R. CEON; M.I. LEÃO; J.C. PEREIRA. Caroço de algodão para vacas 2. Efeito na digestão total e parcial dos nutrientes, taxa de passagem da digesta ruminal e degradação da matéria seca e proteina bruta. R Bras. Zootec., v.26, n.1, p.186-194,1997a.

VILLELA. S. D. J.; S. C. Velasques FILHO; J. F. C SILVA; P.R.CEON; M.I. LEÃO; R.G. ALMEIDA. Caroço de algodão para vacas 3. Efeito na eficiência microbiana, concentração de amônia e pH ruminal. $\mathbf{R}$ Bras. Zootec., v.26, n.1, p.186 -194,1997b.

WU, Z., J.T. Huber, F.T. SLEIMAN, J.M. SIMAS, K.H. CHEN, S.C. CHAN, e c. Fontes. Effect of three suppliemental fat sources on lactation and digestion in dairy cows. J. Dairy Sci. 76:3562. 1993

WU, Z., J.T. Huber, F.T. SLEIMAN, S.C. CHAN, J.M. SIMAS, K.H. CHEN, J.G. VARELA, F. SANTOS, C. FONTES e p. YU. Effect of source and amout of supplemental fat on lactation and digestion in cows. J. Dairy Sci. 77:1644. 1994. 